University of Nebraska - Lincoln

DigitalCommons@University of Nebraska - Lincoln

\title{
Global estimates of evapotranspiration and gross primary production based on MODIS and global meteorology data
}

Wenping Yuan

Beijing Normal University, wenpingyuancn@yahoo.com

Shuguang Liu

U.S. Geological Survey, sliu@usgs.gov

Guirui Yu

Chinese Academy of Sciences, yugr@igsnrr.ac.cn

Jean-Marc Bonnefond

INRA

Jiquan Chen

University of Toledo, jiquan.chen@utoledo.edu

See next page for additional authors

Follow this and additional works at: https://digitalcommons.unl.edu/usgsstaffpub

Yuan, Wenping; Liu, Shuguang; Yu, Guirui; Bonnefond, Jean-Marc; Chen, Jiquan; Davis, Ken; Desai, Ankur R.; Goldstein, Allen H.; Gianelle, Damiano; Rossi, Federica; Suyker, Andrew E.; and Verma, Shashi B., "Global estimates of evapotranspiration and gross primary production based on MODIS and global meteorology data" (2010). USGS Staff -- Published Research. 632.

https://digitalcommons.unl.edu/usgsstaffpub/632

This Article is brought to you for free and open access by the US Geological Survey at DigitalCommons@University of Nebraska - Lincoln. It has been accepted for inclusion in USGS Staff -- Published Research by an authorized administrator of DigitalCommons@University of Nebraska - Lincoln. 


\section{Authors}

Wenping Yuan, Shuguang Liu, Guirui Yu, Jean-Marc Bonnefond, Jiquan Chen, Ken Davis, Ankur R. Desai, Allen H. Goldstein, Damiano Gianelle, Federica Rossi, Andrew E. Suyker, and Shashi B. Verma 


\title{
Global estimates of evapotranspiration and gross primary production based on MODIS and global meteorology data
}

\author{
Wenping Yuan ${ }^{\mathrm{a}, *}$, Shuguang Liu ${ }^{\mathrm{b}, \mathrm{c}}$, Guirui Yu ${ }^{\mathrm{d}, *}$, Jean-Marc Bonnefond ${ }^{\mathrm{e}}$, Jiquan Chen ${ }^{\mathrm{f}}$, Ken Davis ${ }^{\mathrm{g}}$, \\ Ankur R. Desai ${ }^{\mathrm{h}}$, Allen H. Goldstein ${ }^{\mathrm{i}}$, Damiano Gianelle ${ }^{\mathrm{j}}$, Federica Rossi ${ }^{\mathrm{k}}$, \\ Andrew E. Suyker ${ }^{1}$, Shashi B. Verma ${ }^{1}$ \\ ${ }^{a}$ College of Global Change and Earth System Science, Beijing Normal University, Beijing 100875, China \\ ${ }^{\mathrm{b}}$ U.S. Geological Survey (USGS), Earth Resources Observation and Science (EROS) Center, Sioux Falls, South Dakota 57198, USA \\ c Geographic Information Science Center of Excellence, South Dakota State University, Brookings, South Dakota 57007, USA \\ ${ }^{\mathrm{d}}$ Key Laboratory of Ecosystem Network Observation and Modeling, Synthesis Research Center of Chinese Ecosystem Research Network, Institute of Geographic Sciences and Natural Resources Research, \\ Chinese Academy of Sciences, Beijing 100101, China \\ ${ }^{\mathrm{e}}$ INRA, EPHYSE, F-33883 Villenave Dornon, France \\ ${ }^{\mathrm{f}}$ Department of Environmental Sciences, University of Toledo, Toledo, OH 43606, USA \\ ${ }^{\mathrm{g}}$ Earth System Science Center, Pennsylvania State University, University Park, PA 16802, USA \\ ${ }^{\mathrm{h}}$ Atmospheric and Oceanic Sciences Department, University of Wisconsin - Madison, Madison, WI 53706, USA \\ i Department of Environmental Science, Policy, and Management, University of California, Berkeley, CA 94720, USA \\ j Fdn Edmund Mach, IASMA Research and Innovation Centre, I-38100 Trento, Italy \\ k IBIMET-CNR, Via Gobetti,101-40129 Bologna, Italy \\ ${ }^{1}$ School of Natural Resources, University of Nebraska - Lincoln, 807 Hardin Hall, 3310 Holdrege Street, Lincoln, NE 68583-0978, USA
}

\section{A R T I C L E I N F O}

\section{Article history:}

Received 5 August 2009

Received in revised form 22 January 2010

Accepted 30 January 2010

\section{Keywords:}

Gross primary production

Evapotranspiration

EC-LUE model

RS-PM model

Eddy covariance

\begin{abstract}
A B S T R A C T
The simulation of gross primary production (GPP) at various spatial and temporal scales remains a major challenge for quantifying the global carbon cycle. We developed a light use efficiency model, called EC-LUE, driven by only four variables: normalized difference vegetation index (NDVI), photosynthetically active radiation (PAR), air temperature, and the Bowen ratio of sensible to latent heat flux. The EC-LUE model may have the most potential to adequately address the spatial and temporal dynamics of GPP because its parameters (i.e., the potential light use efficiency and optimal plant growth temperature) are invariant across the various land cover types. However, the application of the previous EC-LUE model was hampered by poor prediction of Bowen ratio at the large spatial scale. In this study, we substituted the Bowen ratio with the ratio of evapotranspiration (ET) to net radiation, and revised the RS-PM (Remote Sensing-Penman Monteith) model for quantifying ET. Fifty-four eddy covariance towers, including various ecosystem types, were selected to calibrate and validate the revised RS-PM and EC-LUE models. The revised RS-PM model explained $82 \%$ and $68 \%$ of the observed variations of ET for all the calibration and validation sites, respectively. Using estimated ET as input, the EC-LUE model performed well in calibration and validation sites, explaining $75 \%$ and $61 \%$ of the observed GPP variation for calibration and validation sites respectively. Global patterns of ET and GPP at a spatial resolution of $0.5^{\circ}$ latitude by $0.6^{\circ}$ longitude during the years 20002003 were determined using the global MERRA dataset (Modern Era Retrospective-Analysis for Research and Applications) and MODIS (Moderate Resolution Imaging Spectroradiometer). The global estimates of ET and GPP agreed well with the other global models from the literature, with the highest ET and GPP over tropical forests and the lowest values in dry and high latitude areas. However, comparisons with observed GPP at eddy flux towers showed significant underestimation of ET and GPP due to lower net radiation of MERRA dataset. Applying a procedure to correct the systematic errors of global meteorological data would improve global estimates of GPP and ET. The revised RS-PM and EC-LUE models will provide the alternative approaches making it possible to map ET and GPP over large areas because (1) the model parameters are invariant across various land cover types and (2) all driving forces of the models may be derived from remote sensing data or existing climate observation networks.
\end{abstract}

(c) 2010 Elsevier Inc. All rights reserved.

\footnotetext{
* Corresponding author.

E-mail addresses: wenpingyuancn@yahoo.com (W. Yuan), yugr@igsnrr.ac.cn (G. Yu).
} 


\section{Introduction}

Terrestrial ecosystems drive most of the seasonal and interannual variations in atmospheric carbon dioxide $\left(\mathrm{CO}_{2}\right)$ concentration and have taken up about 20-30\% annual total anthropogenic $\mathrm{CO}_{2}$ emission over the last two and half decades (Canadell et al., 2007). However, the geographic locations of this absorption are not well known (Friend et al., 2007). Moreover, atmospheric measurements and inverse modeling suggest that net terrestrial carbon uptake substantially increased from the 1980s to the 1990s (Battle et al., 2006; Bousquet et al., 2000), but the causes of these increases are not well understood (Schimel et al., 2001). Vegetation gross primary production (GPP) quantifies the gross carbon fixed by vegetation in terrestrial ecosystems; in effect, it is the beginning of the carbon biogeochemical cycle and the principal indicator of biosphere carbon fluxes. Therefore, GPP is of great importance to the processes and factors regulating the terrestrial carbon sink.

A number of ecosystem models have been widely applied as a means of quantifying spatio-temporal variations in GPP at large scales (Cao \& Woodward, 1998; Cramer et al., 1999; Yuan et al., 2007). However, different ecosystem models are inconclusive regarding the magnitude and spatial distribution of GPP at the regional and global scales. For example, Cramer et al. (1999) compared 16 dynamic global vegetation models and suggested the lowest estimation of global NPP (39.9 Pg C) by the Hybrid model was approximately 50\% smaller compared to what was estimated by the TURC model (Terrestrial Uptake and Release of Carbon) (80.5 Pg C). Model outputs were indicated by low confidence at regional and global scales due to several major limitations: (1) spatial and temporal heterogeneity of ecosystem processes used by models; (2) nonlinearity of the functional responses of ecosystem processes to environmental variables; (3) requirement of both physiological or site-specific parameters; and (4) inadequate validation against observation (Baldocchi et al., 1996; Friend et al., 2007).

The Light Use Efficiency (LUE) model may have the most potential to adequately address the spatial and temporal dynamics of GPP because it presents the consistent ecosystem processes across the various vegetation types (Running et al., 2000), avoiding the problems on responsive nonlinearity of ecosystem processes to environmental variables. The LUE model is built upon two fundamental assumptions (Running et al., 2004): (1) that ecosystem GPP is directly related to Absorbed Photosynthetically Active Radiation (APAR) through LUE, where LUE is defined as the amount of carbon produced per unit of APAR and (2) that realized LUE may be reduced below its theoretical potential value by environmental stresses such as low temperatures or water shortages (Landsberg, 1986). The general form of the LUE model is:

$\mathrm{GPP}=\mathrm{PAR} \times f \mathrm{PAR} \times \varepsilon_{\max } \times f$

where PAR is the incident photosynthetically active radiation $\left(\mathrm{MJ} \mathrm{m}^{-2}\right)$ per time period (e.g., day or month), fPAR is the fraction of PAR absorbed by the vegetation canopy, $\varepsilon_{\max }$ is the potential $L U E\left(\mathrm{~g} \mathrm{C} \mathrm{m}^{-2}\right.$ $\mathrm{MJ}^{-1}$ APAR) without environment stress, and $f$ is a scalar varying from 0 to 1 and represents the effects of temperature, moisture, and other environmental conditions on LUE.

We have developed a LUE model for simulating daily GPP, named the EC-LUE (Eddy Covariance Light Use Efficiency) model, derived by satellite data and eddy covariance measurements (Yuan et al., 2007). The EC-LUE model was calibrated and validated using estimated GPP from eddy covariance towers at the AmeriFlux and EuroFlux networks, covering a variety of forests, grasslands, and savannas. More importantly, parameters of the EC-LUE model are invariant across various vegetation types, which make it possible to map daily GPP over large areas. The EC-LUE model uses the Bowen ratio of sensible to latent heat flux to present the moisture constraint to LUE, which hampers its applications due to the poor simulation of sensible and latent heat flux at large spatial scales. In addition, EC-LUE has not been validated at cropland ecosystems as a major ecosystem type impacting the regional and global carbon budgets.

Besides driving the EC-LUE model for simulating GPP, evapotranspiration (ET, equivalent of latent heat) over land is a key component of the climate system as it links the hydrological, energy, and carbon cycles (Dirmeyer, 1994; Betts \& Ball, 1997; Pielke et al., 1998). Accurate knowledge on temporal and spatial variations of ET is critical for understanding the interactions between land surfaces and the atmosphere, improving water and land resource management (Meyer, 1999; Raupach, 2001), drought detection and assessment (McVicar \& Jupp, 1998), and regional hydrological applications (Kustas \& Norman, 1996; Keane et al., 2002). However, ET remains the most problematic component of the water cycle because of the heterogeneity of the landscape and the large number of controlling factors involved, including climate, plant biophysics, soil properties, and topography (Gash, 1987; Friedl, 1996; Lettenmaier \& Famiglietti, 2006). Remotely sensed data provides us with temporally and spatially continuous information over vegetated surfaces and is useful for accurately parameterizing surface biophysical variables, such as leaf area index (LAI), and vegetation cover, which can be used to develop a remotely sensed ET model.

Eddy covariance (EC) measurements recorded by the increasing number of EC towers offer the best opportunity for estimating vegetation productivity and calibrating or validating ecosystem models. The concurrent measurements of meteorological variables such as temperature and vapor pressure, as well as water balance variables including evapotranspiration and soil water statue, provide unprecedented datasets for investigating the dynamics and driving variables of GPP. The $\mathrm{CO}_{2} \mathrm{EC}$ flux data now play a growing role in evaluating process- and satellite-based models (Law et al., 2000). The network of EC towers (e.g., AmeriFlux) now covers a wide range of biomes in contrast to most previous efforts, which focused on individual sites or biomes. The overarching goals of this study are to (1) refine GPP and ET models for mapping GPP and ET across the regional scales, and (2) investigate the spatial patterns of GPP and ET.

\section{Models and data}

\subsection{Revised Remote Sensing-Penman Monteith (RS-PM) model}

The RS-PM model was originally proposed by Cleugh et al. (2007). Mu et al. (2007) revised it by adding a soil evaporation component, using moisture and temperature constraints on stomatal conductance, and upscaling canopy conductance with leaf area index. In this study, we revised the equations dealing with temperature constraint for stomatal conductance and energy allocation between vegetation canopy and soil surface.

$\mathrm{Mu}$ et al. (2007) calculated the temperature and moisture constraints for stomatal conductance ( $m_{\mathrm{VPD}}$ and $m_{\mathrm{TM}}$ ) as:

$$
\begin{gathered}
m_{\mathrm{VPD}}= \begin{cases}1.0 & \mathrm{VPD} \leq \mathrm{VPD}_{\text {open }} \\
\frac{\mathrm{VPD}_{\text {close }}-\mathrm{VPD}}{\mathrm{VPD}_{\text {close }}-\mathrm{VPD}_{\text {open }}} & \mathrm{VPD}_{\text {open }}<\mathrm{VPD}<\mathrm{VPD}_{\text {close }} \\
0.1 & \mathrm{VPD} \geq \mathrm{VPD}_{\text {close }}\end{cases} \\
m_{\mathrm{TM}}= \begin{cases}1.0 & \mathrm{TM} \geq \mathrm{TM}_{\text {open }} \\
\frac{\mathrm{TM}-\mathrm{TM}_{\text {close }}}{\mathrm{TM}_{\text {open }}-\mathrm{TM}_{\text {close }}} & \mathrm{TM}_{\text {close }}<\mathrm{TM}<\mathrm{TM}_{\text {open }} \\
0.1 & \mathrm{TM} \leq \mathrm{TM}_{\text {close }}\end{cases}
\end{gathered}
$$

where close indicates nearly complete inhibition (full stomatal closure) and open indicates no inhibition to transpiration, $T M$ is minimum air temperature $\left({ }^{\circ} \mathrm{C}\right)$, and $V P D$ is vapor pressure deficit 
(kPa). Studies have demonstrated, however, that high air temperature significantly decreases leaf stomatal conductance by closing stomata and causing structure defects (Schreiber et al., 2001). In our revised RS-PM algorithm, the temperature constraint for stomatal conductance follows the equation detailed by June et al. (2004) and Fisher et al. (2008) with an optimum $T_{\text {opt }}$ set as $25^{\circ} \mathrm{C}$.

$m_{T}=\exp \left(-\left(\frac{T-T_{\mathrm{opt}}}{T_{\mathrm{opt}}}\right)^{2}\right)$

where $T$ is air temperature.

Net radiation $\left(R_{\mathrm{n}}\right)$ is linearly partitioned between the canopy and the soil surface using vegetation cover fraction $\left(F_{\mathrm{c}}\right)$ in the study of $\mathrm{Mu}$ et al. (2007), such that:

$A_{\mathrm{c}}=F_{\mathrm{c}} \times R_{\mathrm{n}}$

$A_{\text {soil }}=\left(1-F_{\mathrm{c}}\right) \times R_{\mathrm{n}}$

where $A_{c}$ and $A_{\text {soil }}$ are the total net incoming radiation partitioned to the canopy and soil, respectively. $F_{\mathrm{c}}$ is defined as the fraction of ground surface covered by the maximum extent of the vegetation canopy (varies between 0 and 1 ). Mu et al. (2007) calculated $F_{\mathrm{c}}$ using EVI:

$F_{\mathrm{c}}=\frac{\mathrm{EVI}-\mathrm{EVI}_{\min }}{\mathrm{EVI}_{\max }-\mathrm{EVI}_{\min }}$

where $E V I_{\min }$ and $E V I_{\max }$ are the signals from bare soil $(\mathrm{LAI} \rightarrow 0)$ and dense green vegetation (LAI $\rightarrow \infty$ ), which are set as seasonally and geographically invariant constants 0.05 and 0.95 , respectively. However, a number of studies have shown that irradiance decrease exponentially with increasing canopy depth (Foroutan-Pour et al., 2001; Gholz et al., 1991; Monsi \& Saeki, 1953; Vose et al., 1995). In our revised RS-PM algorithm, we used the Beer-Lambert law to exponentially partition net radiation between the canopy and the soil surface (Ruimy et al., 1999):

$A_{\text {soil }}=R_{\mathrm{n}} \times \exp (-k \times \mathrm{LAI})$

$A_{\mathrm{c}}=R_{\mathrm{n}}-A_{\text {soil }}$

where $L A I$ is leaf area index, and $k$ is extinction coefficient (0.5).

In addition, Mu et al. (2007) used a biome properties look-up table to determine the parameters: $T M_{\text {open }}, T M_{\text {close }}, V P D_{\text {close }}$, and $V P D_{\text {open }}$ in the Eqs. (2) and (3). We conducted two sensitivity experiments in order to examine the necessity of varying parameters with ecosystem types: (1) setting $T M_{\text {open }}$ and $V P D_{\text {close }}$ as the maximum value $\left(12{ }^{\circ} \mathrm{C}\right.$ and $3.9 \mathrm{kPa})$ and $T M_{\text {close }}$ and $V P D_{\text {open }}$ as minimum value $\left(-8{ }^{\circ} \mathrm{C}\right.$ and $0.65 \mathrm{kPa}$ ) in the study of $\mathrm{Mu}$ et al. (2007) for all study sites (see Table 1 of Mu et al. (2007)); and (2) setting $T M_{\text {open }}$ and $V P D_{\text {close }}$ as the minimum value $\left(8.31{ }^{\circ} \mathrm{C}\right.$ and $\left.2.5 \mathrm{kPa}\right)$ and $T M_{\text {close }}$ and $V P D_{\text {open }}$ as maximum value $\left(-6{ }^{\circ} \mathrm{C}\right.$ and $\left.0.93 \mathrm{kPa}\right)$ for all study sites, respectively. There were not much differences of model simulations between the two model experiments among various ecosystem types. The maximum difference of RPE (relative predictive errors, see Eq. (12)) occurred at deciduous broadleaf forest with $2.9 \%$ and average value was $2.4 \%$ in all the ecosystem types. The maximum difference in coefficient of determination was 0.04 at evergreen broadleaf forest, and average difference was 0.02 at all ecosystem types. Therefore, it is possible to set invariant model parameters across the various vegetation types. We calibrated three parameters in the revised RSPM model: $V P D_{\text {close, }}$ total aerodynamic conductance to vapor transport $\left(C_{\text {tot }}\right.$, the sum of soil surface conductance and the aerodynamic conductance for vapor transport), and mean potential stomatal conductance $\left(C_{1}\right)$ using observed ET from all eddy flux towers in order to set constant parameters for all vegetation types.

\subsection{EC-LUE model}

The EC-LUE model is driven by only four variables: normalized difference vegetation index (NDVI), photosynthetically active radiation (PAR), air temperature, and the Bowen ratio of sensible to latent heat flux. However, previous applications of the EC-LUE model were hampered by poor simulation of the Bowen ratio of sensible to latent heat flux at large spatial scales, which was used to present the moisture constraint on light use efficiency:

$W_{\mathrm{s}}=\frac{1}{\beta+1}=\frac{\mathrm{LE}}{\mathrm{LE}+H}$

where $\beta$ is the Bowen ratio, and $L E$ and $H$ are ecosystem latent $\left(\mathrm{MJ} \mathrm{m}^{-2}\right.$ ) and sensible heat flux $\left(\mathrm{MJ} \mathrm{m}{ }^{-2}\right.$ ). In this study, we used $R_{\mathrm{n}}$ to substitute the sum of $L E$ and $H$, and revised downward-regulation scalar for moisture on LUE as:

$W_{\mathrm{s}}=\frac{\mathrm{LE}}{R_{\mathrm{n}}}$

LE is equivalence of ET, which could be estimated by the revised RS-PM model across the large spatial scales. $R_{\mathrm{n}}$ can be derived from existing climate observation networks (Zhang et al., 2004).

\subsection{Data at the EC sites}

The EC data were used in this study to calibrate and validate the revised RS-PM and EC-LUE model from the AmeriFLUX (http://public. ornl.gov/ameriflux) and EuroFLUX internet Web pages (http://www. fluxnet.ornl.gov/fluxnet/index.cfm; Valentini, 2003). Fifty-four EC sites were included in this study (Table 1), covering six major terrestrial biomes: deciduous broadleaf forests, mixed forests, evergreen needleleaf forests, grasslands, savannas, and croplands. Supplementary information on the vegetation, climate, and soil at each site is available on-line. Half-hourly or hourly averaged global radiation $\left(R_{\mathrm{g}}\right)$, photosynthetically active radiation (PAR), air temperature $\left(T_{\mathrm{a}}\right)$, and friction velocity $\left(u^{*}\right)$ were used together with net ecosystem exchange of $\mathrm{CO}_{2}$ (NEE) in this study. When available, datasets that were gap-filled by site PIs were used for this study. For other sites, data filtering and gap-filling were conducted according to the following procedures.

An outlier ("spike") detection technique was applied, and the spikes were removed, following Papale et al. (2006). Because nighttime $\mathrm{CO}_{2}$ flux can be underestimated by eddy covariance measurements under stable conditions (Falge et al., 2001), nighttime data with nonturbulent conditions were removed based on a $u^{*}$-threshold criterion (site-specific 99\% threshold criterion following Papale et al., 2006, and Reichstein et al., 2005).

Nonlinear regression methods were used for filling NEE data gaps (Falge et al., 2001). Nonlinear regression relationships between measured fluxes and environmental factors were fit using a 15-day moving window. The Vant Hoff (" $\mathrm{Q}_{10}$ "; see Lloyd \& Taylor, 1994) equation was used to fill the missing nighttime fluxes ( $\left.N E E_{\text {night }}\right)$ :

$\mathrm{NEE}_{\text {night }}=A e^{(B T)}$

where, $A$ and $B$ are fit model parameters, $T$ is air temperature $\left({ }^{\circ} \mathrm{C}\right)$. A Michaelis-Menten light response equation was used to fill the missing daytime fluxes ( $N E E_{\text {day }}$ ) (Falge et al., 2001):

$\mathrm{NEE}_{\text {day }}=\frac{\alpha \times \mathrm{PAR} \times F_{\mathrm{GPP}, \mathrm{sat}}}{F_{\mathrm{GPP}, \mathrm{sat}}+\alpha \times \mathrm{PAR}}-\mathrm{Re}_{\mathrm{day}}$

where $F_{\mathrm{GPP}, \mathrm{sat}}$ (gross primary productivity at saturating light) and $\alpha$ (initial slope of the light response function) are fit parameters, and 
Table 1

Name, location, vegetation type and available years of the study sites used for model calibration and validation.

\begin{tabular}{|c|c|c|c|c|}
\hline Site & Latitude, longitude & Vegetation type & Available years & Reference \\
\hline \multicolumn{5}{|l|}{ Calibration sites } \\
\hline Aspen & $53.62^{\circ} \mathrm{N}, 106.19^{\circ} \mathrm{W}$ & DBF & 2002-2005 & Griffis et al. (2003) \\
\hline Burn87 & $63.92^{\circ} \mathrm{N}, 145.37^{\circ} \mathrm{W}$ & DBF & 2002-2004 & Liu and Randerson (2008) \\
\hline Chestnut & $35.93^{\circ} \mathrm{N}, 84.33^{\circ} \mathrm{W}$ & $\mathrm{DBF}$ & 2006 & / \\
\hline Goodwincreek & $34.25^{\circ} \mathrm{N}, 89.97^{\circ} \mathrm{W}$ & DBF & 2002-2006 & / \\
\hline Toledo & $41.55^{\circ} \mathrm{N}, 83.84^{\circ} \mathrm{W}$ & DBF & 2004-2005 & / \\
\hline Willowcreek & $45.90^{\circ} \mathrm{N}, 90.07^{\circ} \mathrm{W}$ & DBF & 2000-2006 & Cook et al. (2004) \\
\hline Puechabon & $43.73^{\circ} \mathrm{N}, 3.58^{\circ} \mathrm{E}$ & EBF & 2000-2003 & Rambal et al. (2004) \\
\hline Blackspruce & $53.98^{\circ} \mathrm{N}, 105.12^{\circ} \mathrm{W}$ & ENF & 2000-2005 & Griffis et al. (2003) \\
\hline Boeas_nsa & $55.87^{\circ} \mathrm{N}, 98.48^{\circ} \mathrm{W}$ & ENF & $2000-2004$ & Dunn et al. (2007) \\
\hline Dukepine & $35.97^{\circ} \mathrm{N}, 79.09^{\circ} \mathrm{W}$ & ENF & 2000-2005 & Stoy et al. (2008) \\
\hline Howland & $45.20^{\circ} \mathrm{N}, 68.74^{\circ} \mathrm{W}$ & ENF & $2000-2004$ & Hollinger et al. (2004) \\
\hline Jackpine & $53.91^{\circ} \mathrm{N}, 104.69^{\circ} \mathrm{W}$ & ENF & 2000-2003 & Griffis et al. (2003) \\
\hline Tharandt & $50.95^{\circ} \mathrm{N}, 13.56^{\circ} \mathrm{E}$ & ENF & 2000-2003 & Grünwald and Berhofer (2007) \\
\hline Uci1964 & $55.91^{\circ} \mathrm{N}, 98.38^{\circ} \mathrm{W}$ & ENF & 2001-2005 & Goulden et al. (2006) \\
\hline Uci1989 & $55.91^{\circ} \mathrm{N}, 98.96^{\circ} \mathrm{W}$ & ENF & 2003-2005 & / \\
\hline Windriver & $45.82^{\circ} \mathrm{N}, 121.95^{\circ} \mathrm{W}$ & ENF & 2004-2006 & Paw et al. (2004) \\
\hline Dukegrass & $35.97^{\circ} \mathrm{N}, 79.09^{\circ} \mathrm{W}$ & GRS & 2001-2005 & Novick et al. (2004) \\
\hline Walnutriver & $37.52^{\circ} \mathrm{N}, 96.85^{\circ} \mathrm{W}$ & GRS & 2001-2004 & Song et al. (2005) \\
\hline Lavarone & $45.95^{\circ} \mathrm{N}, 11.26^{\circ} \mathrm{E}$ & MIX & 2000-2002 & Fiora and Cescatti (2006) \\
\hline Sylvania & $46.24^{\circ} \mathrm{N}, 89.34^{\circ} \mathrm{W}$ & MIX & 2002-2006 & Desai et al. (2005) \\
\hline Winmahard & $46.63^{\circ} \mathrm{N}, 91.09^{\circ} \mathrm{W}$ & MIX & 2004 & l \\
\hline \multicolumn{5}{|l|}{ Validation sites } \\
\hline Bondville & $40.00^{\circ} \mathrm{N}, 88.29^{\circ} \mathrm{W}$ & CRP & 2002-2006 & Meyers and Hollinger (2004) \\
\hline Meadirrigated & $41.16^{\circ} \mathrm{N}, 96.47^{\circ} \mathrm{W}$ & CRP & 2001-2004 & Verma et al. (2005) \\
\hline Meadirrrotate & $41.16^{\circ} \mathrm{N}, 96.47^{\circ} \mathrm{W}$ & CRP & 2001-2004 & Verma et al. (2005) \\
\hline Meadrainfed & $41.17^{\circ} \mathrm{N}, 96.43^{\circ} \mathrm{W}$ & CRP & 2001-2004 & Verma et al. (2005) \\
\hline Dukehardwood & $35.97^{\circ} \mathrm{N}, 79.10^{\circ} \mathrm{W}$ & $\mathrm{DBF}$ & 2001-2005 & Pataki and Oren (2003) \\
\hline Hainich & $51.06^{\circ} \mathrm{N}, 10.45^{\circ} \mathrm{E}$ & DBF & 2000-2003 & Knohl et al. (2003) \\
\hline Hesse & $48.66^{\circ} \mathrm{N}, 7.05^{\circ} \mathrm{E}$ & $\mathrm{DBF}$ & $2000-2003$ & Granier et al. (2000) \\
\hline Indianammsf & $39.32^{\circ} \mathrm{N}, 86.41^{\circ} \mathrm{W}$ & $\mathrm{DBF}$ & $2000-2003$ & Schmid et al. (2000) \\
\hline Walkerbrach & $35.95^{\circ} \mathrm{N}, 84.28^{\circ} \mathrm{W}$ & DBF & 2000-2001, 2004 & Wilson and Baldocchi (2000) \\
\hline ParcoTicino & $45.20^{\circ} \mathrm{N}, 9.05^{\circ} \mathrm{E}$ & DBF & 2003 & Migliavacca et al. (2009) \\
\hline Austincary & $29.73^{\circ} \mathrm{N}, 82.21^{\circ} \mathrm{W}$ & EBF & 2005-2006 & Gholz and Clark (2002) \\
\hline Blackhill & $44.15^{\circ} \mathrm{N}, 103.65^{\circ} \mathrm{W}$ & ENF & 2004-2006 & l \\
\hline Blodgett & $38.89^{\circ} \mathrm{N}, 120.63^{\circ} \mathrm{W}$ & ENF & $2001-2004$ & Goldstein et al. (2000) \\
\hline Control & $63.89^{\circ} \mathrm{N}, 145.74^{\circ} \mathrm{W}$ & ENF & 2002-2004 & Liu and Randerson (2008) \\
\hline Donaldson & $29.75^{\circ} \mathrm{N}, 82.16^{\circ} \mathrm{W}$ & ENF & $2000-2003$ & Gholz and Clark (2002) \\
\hline LeBray & $44.71^{\circ} \mathrm{N}, 0.76^{\circ} \mathrm{E}$ & ENF & 2000, 2003 & Berbigier et al. (2001) \\
\hline Metoliusmidpine & $44.45^{\circ} \mathrm{N}, 121.55^{\circ} \mathrm{W}$ & ENF & $2002-2005$ & Law et al. (2004) \\
\hline Metoliusoldyoung & $44.43^{\circ} \mathrm{N}, 121.56^{\circ} \mathrm{W}$ & ENF & $2000-2002$ & Law et al. (2000) \\
\hline Niwotridge & $40.03^{\circ} \mathrm{N}, 105.54^{\circ} \mathrm{W}$ & ENF & 2000-2004 & Monson et al. (2005) \\
\hline Uci1930 & $55.90^{\circ} \mathrm{N}, 98.52^{\circ} \mathrm{W}$ & ENF & 2001-2004 & Goulden et al. (2006) \\
\hline Uci1981 & $55.86^{\circ} \mathrm{N}, 98.48^{\circ} \mathrm{W}$ & ENF & $2002-2003$ & Goulden et al. (2006) \\
\hline Uci1998 & $56.63^{\circ} \mathrm{N}, 99.94^{\circ} \mathrm{W}$ & ENF & $2002-2005$ & Goulden et al. (2006) \\
\hline Wetzstein & $50.45^{\circ} \mathrm{N}, 11.45^{\circ} \mathrm{E}$ & ENF & 2002-2003 & Anthoni et al. (2004) \\
\hline Winmared & $46.73^{\circ} \mathrm{N}, 91.16^{\circ} \mathrm{W}$ & ENF & 2004-2005 & Noormets et al. (2007) \\
\hline Burn99 & $63.92^{\circ} \mathrm{N}, 145.74^{\circ} \mathrm{W}$ & GRS & $2002-2004$ & Liu and Randerson (2008) \\
\hline Canaanvalley & $39.06^{\circ} \mathrm{N}, 79.42^{\circ} \mathrm{W}$ & GRS & 2004 & / \\
\hline Lethbridge & $49.70^{\circ} \mathrm{N}, 112.94^{\circ} \mathrm{W}$ & GRS & 2000-2001 & Flanagan and Johnson (2005) \\
\hline Monte Bondone & $38.53^{\circ} \mathrm{N}, 8.00^{\circ} \mathrm{E}$ & GRS & 2001 & Marcolla and Cescatti (2005) \\
\hline Vairaranch & $38.40^{\circ} \mathrm{N}, 120.95^{\circ} \mathrm{W}$ & GRS & 2001-2006 & Ryu et al. (2008) \\
\hline Fortdix & $39.97^{\circ} \mathrm{N}, 74.43^{\circ} \mathrm{W}$ & MIX & 2006 & / \\
\hline Nonantola & $44.68^{\circ} \mathrm{N}, 11.08^{\circ} \mathrm{E}$ & MIX & 2001-2003 & / \\
\hline Umichigan & $45.55^{\circ} \mathrm{N}, 84.71^{\circ} \mathrm{W}$ & MIX & 2000-2006 & Curtis et al. (2005) \\
\hline Tonzi Ranch & $38.43^{\circ} \mathrm{N}, 120.96^{\circ} \mathrm{W}$ & SAV & $2002-2006$ & Ma et al. (2007) \\
\hline
\end{tabular}

DBF: deciduous broadleaf fores; EBF: evergreen broadleaf forest; ENF: evergreen needleleaf forest; GRS: grassland; MIX: mixed forest; CRP: cropland; SAV: savanna.

$R e_{\text {day }}$ (ecosystem respiration during the day) was estimated by extrapolation of Eq. (10) using the daytime air temperature.

Daily NEE, Re, and meteorological variables were synthesized based on half-hourly or hourly values and the daily values were indicated as missing when missing data was more than $20 \%$ of entire data at a given day, otherwise daily values were calculated by multiplying averaged hourly rate by 24 (hours). GPP was calculated as the sum of NEE and Re. Based on the daily dataset, yearly values of various variables can be calculated by multiplying averaged daily rate by 365 (days). If missing daily data was more than $20 \%$ of entire year data, the value of this year was indicated as missing.
Normalized difference vegetation index (NDVI) and leaf area index (LAI) for the sites were determined from the Moderate Resolution Imaging Spectroradiometer (MODIS). MODIS ASCII subset data were used in this study and generated from MODIS Collection 5 data, which was downloaded directly from the Oak Ridge National Laboratory Distributed Active Center (ORNL DAAC) Web site. The 8-day MODIS LAI (MOD15A2) and 16-day MODIS NDVI (MOD13A2) data at 1-km spatial resolution were the basis for models verification in the flux sites. Only the NDVI and LAI values of the pixel containing the tower were used. Quality control (QC) flags, which signal cloud contamination in each pixel, were examined to screen and reject NDVI and LAI data of insufficient quality. 


\subsection{Data at the global scale}

For global estimates of ET and GPP, we used input datasets for net radiation $\left(R_{\mathrm{n}}\right)$, air temperature $(T)$, relative humidity $\left(R_{\mathrm{h}}\right)$ and photosynthetically active radiation (PAR) from the MERRA (Modern Era Retrospective-Analysis for Research and Applications) archive for 2000-2003 (Global Modeling and Assimilation Office, 2004). MERRA is a NASA reanalysis for the satellite era using a major new version of the Goddard Earth Observing System Data Assimilation System Version 5 (GEOS-5). MERRA uses data from all available surface weather observations globally every $3 \mathrm{~h}$, and GEOS-5 was used to interpolate and grid these point data on a short time sequence, and produces an estimate of climatic conditions for the world, at 10 meters above the land surface (approximating canopy height conditions) and at a resolution of $0.5^{\circ}$ latitude by $0.6^{\circ}$ longitude.
MERRA reanalyses dataset has been validated carefully at the global scale using surface meteorological data sets to evaluate the uncertainty of various meteorological factors (e.g. temperature, radiation, humidity, energy balance), which showed MERRA considerably reduced the energy and water imbalance. Detailed information on the MERRA dataset is available at the website (http://gmao.gsfc.nasa. gov/research/merra/).

The global 8-day MODIS LAI (MOD15A2) and 16-day MODIS NDVI (MOD13A2) data were used in this study. Quality control (QC) flags were examined to screen and reject NDVI and LAI data of insufficient quality. We temporally filled the missing or unreliable LAI and NDVI at each 1-km MODIS pixel based on their corresponding quality assessment data fields as proposed by Zhao et al. (2005). If the first (or last) 8-day LAI (16-day NDVI) data are unreliable or missing, they will be replaced by the closest reliable 8-day (16-day) values.
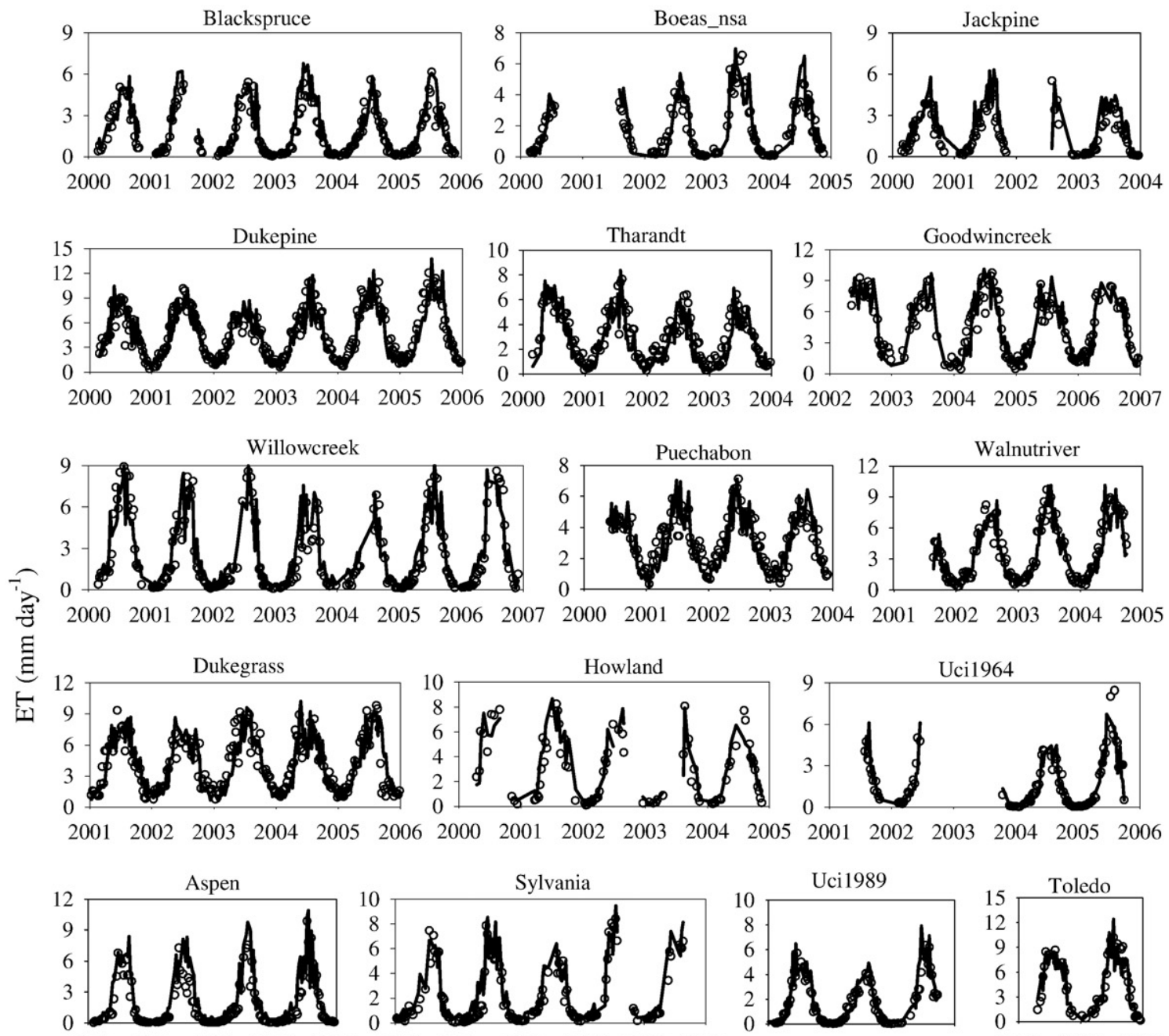

Uci1964
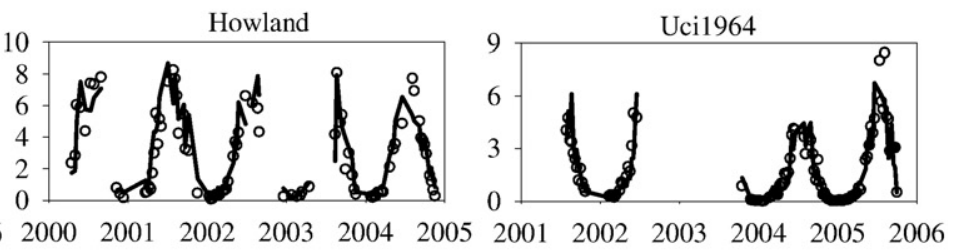

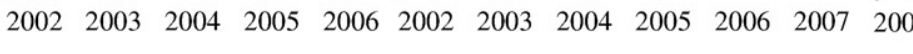
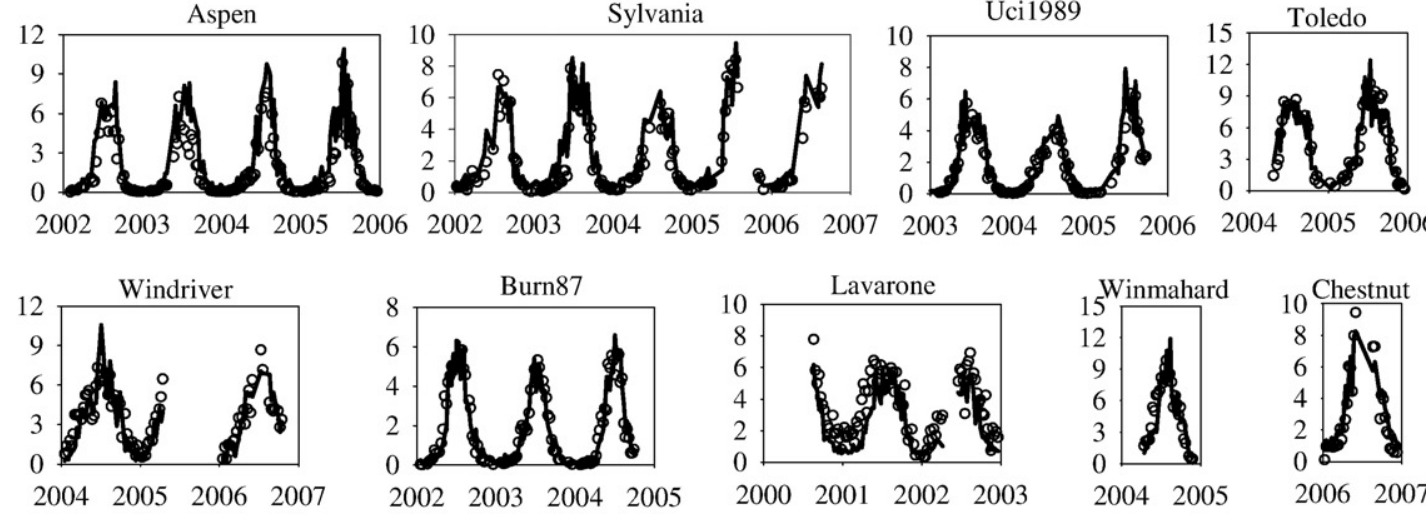

Year

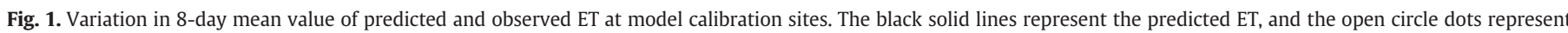
observed ET. 


\subsection{Nonlinear optimization and statistical analysis}

The nonlinear regression procedure (Proc NLIN) in the Statistical Analysis System (SAS, SAS Institute Inc., Cary, NC, USA) was applied to two calculations: (1) to determine the parameter values in the equation filling NEE data gaps and calculating daytime ecosystem respiration (i.e., Eqs. (10) and (11)), and (2) to optimize the values for $\mathrm{VPD}_{\text {close }}, R_{\text {tot }}$ and $C_{1}$ in the revised RS-PM model (see Mu et al., 2007), and $T_{\text {opt }}$ and $\varepsilon_{\max }$ (see Yuan et al., 2007) in the EC-LUE model across all the calibration sites.
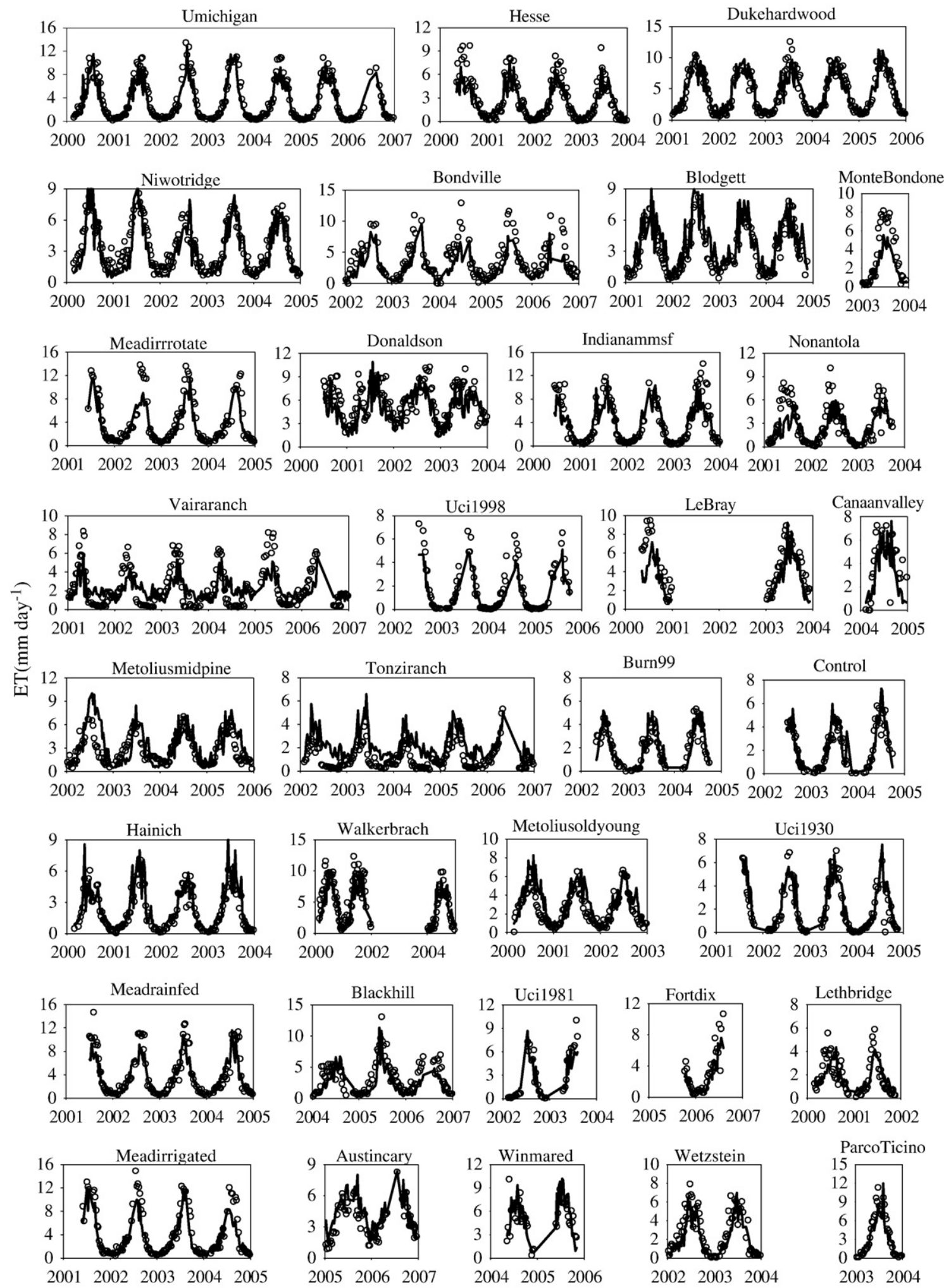

Year 
Three metrics were used to evaluate the performance of the revised RS-PM and EC-LUE model in this study:

(1) The coefficient of determination, $R^{2}$, representing how much variation in the observations was explained by the models.

(2) Absolute predictive error (PE), quantifying the difference between simulated and observed values:

$\mathrm{PE}=\bar{S}-\bar{O}$

where $\overline{\mathrm{S}}$ and $\overline{\mathrm{O}}$ are mean simulated and mean observed values, respectively.

(3) Relative predictive error (RPE), computed as:

$$
\mathrm{RPE}=\frac{\bar{S}-\bar{O}}{\bar{O}} \times 100 \%
$$

\section{Results}

\subsection{Calibration and validation of the revised RS-PM model}

Twenty-one sites were selected to calibrate the revised RS-PM model, and other thirty-three sites were to validate the model (Table 1). Both calibration and validation sites covered several dominant natural and agricultural ecosystem types, including: evergreen needleleaf forests, mixed forests, deciduous broadleaf forests, grasslands, savannas, and croplands.

The calibrated values for $C_{\text {tot }}, C_{1}$ and $V_{P D}$ close were $0.008 \mathrm{~m} \mathrm{~s}^{-1}$, $0.003 \mathrm{~m} \mathrm{~s}^{-1}$, and $2.79 \mathrm{kPa}$ in the revised RS-PM model, respectively. Fig. 1 shows the range of predicted ET and observed ET at the 21 calibration sites (Fig. 1). The model also successfully predicted the magnitudes and seasonal variations of the observed ET at the validation sites (Fig. 2). Collectively, the revised RS-PM model explained about $82 \%$ of the variation of 8 -day ET at all calibration sites (Fig. 3a). Model performance was similar to that at the calibration sites and explained $68 \%$ of the ET variations at these new sites (Fig. 3b).

However, large differences between predicted and observed ET still existed in a few sites. Predicted ET values were higher than observed ET at Aspen, Jackpine, and Tonzi Ranch with RPE values of $41 \%, 30 \%$, and $93 \%$, respectively (Table 2 ). The model underestimated the ET at Bondville, Monte Bondone, and Canaanvalley with the RPE varying from $31 \%$ to $39 \%$. At the other 48 sites, the RPE values were lower than $30 \%$.

Our revised RS-PM algorithm improved the ET estimates at most of the 54 flux towers compared with these estimated using the original RS-PM algorithm, and reduced RPE at 36 of the 54 flux tower sites (data not shown). The average absolute value of RPE of the 8-day latent heat fluxes over the 54 flux towers was decreased using the revised RS-PM algorithm to $15 \%$ compared with the $22 \%$ of the original algorithm. The coefficient of determination $\left(R^{2}\right)$ between the ET estimates and observations for the 8-day results are higher at 48 sites, averaging 0.78 using revised RS-PM algorithm and 0.67 using the original version.

Fig. 4 showed the model performance of our revised RS-PM model driven by tower-specific meteorology and the global MERRA meteorology dataset, respectively. The model driven by towerspecific meteorology data explained $83 \%$ variations of annual mean ET across 54 flux sites (Fig. 4a), and provided no systematic errors in model predictions. In contrast, using the MERRA dataset significantly decreased model performance, and explained $67 \%$ of the variations of ET and underestimated ET at the most sites (Fig. 4b).

\subsection{Calibration and validation of EC-LUE model}

Using ET simulated by the revised RS-PM model, the calibrated values for optimal temperature and potential LUE were $21{ }^{\circ} \mathrm{C}$ and $2.25 \mathrm{~g} \mathrm{C} \mathrm{MJ}^{-1}$. The EC-LUE model successfully predicted the magnitudes and seasonal variations of the estimated GPP from EC measurements at calibration and validation sites (Figs. 5, 6). The model explained about $75 \%$ and $61 \%$ of the variation of 8 -day GPP estimated at calibration and validation sites, respectively (Fig. 7). There were no significant systematic errors in model predictions. Although the ECLUE model explained significant amounts of GPP variability at the individual sites, large differences between predicted GPP and estimated GPP values from EC measurements still existed at a few sites. The model underestimated GPP at several European sites (e.g., Hesse, MonteBondone and Nonantola) with RPE higher than 40\% (Table 2). Predictions were higher than observed for GPP at several high latitude sites (Uci 1989, Uci1930, Uci1998 and Burn99) and at Tonzi Ranch PE values varied from $0.41 \mathrm{~g} \mathrm{C} \mathrm{m}^{-2}$ day $^{-1}$ to $1.25 \mathrm{~g} \mathrm{C} \mathrm{m}^{-2}$ day $^{-1}$ and RPE values from $35 \%$ to $63 \%$, respectively. At the other 37 sites, the ECLUE model gave accurate predictions with RPE values lower than 30\% (Table 2).

Using net radiation to substitute the sum of $\mathrm{H}$ and $\mathrm{LE}$, the revised EC-LUE algorithm generally performed worse than the original GPP algorithm at most of the 54 flux sites. The revised EC-LUE model produced higher predictive errors at 35 of the 54 flux towers, and the absolute RPE of the 8-day GPP increased from $18 \%$ of the original ECLUE algorithm to $24 \%$ using the revised algorithm. The coefficient of determination $\left(R^{2}\right)$ between the GPP estimates and observations for the 8-day results decreases from 0.89 of original EC-LUE to 0.73 of revised version. Predictive errors of ET significantly induced the biases

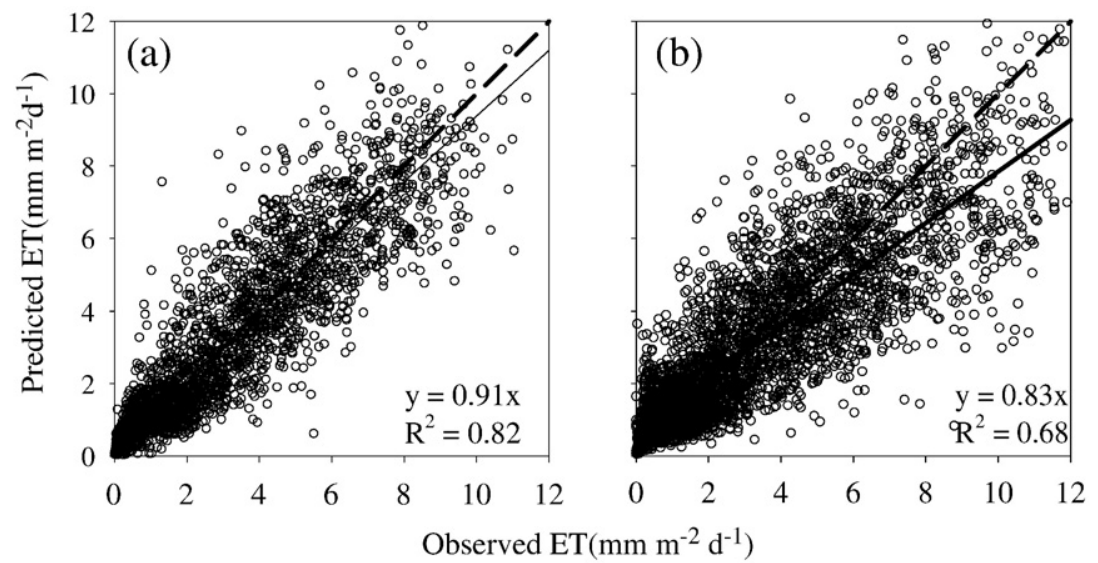

Fig. 3. Observed and predicted ET at the model calibration (a) and validation (b) sites in Table 1. The short dash lines are 1:1 line and the solid lines are linear regression line. 
Table 2

Predicted results of the revised RS-PM and EC-LUE model at calibration and validation sites.

\begin{tabular}{|c|c|c|c|c|c|c|c|c|c|c|}
\hline \multirow[t]{2}{*}{ Site } & \multicolumn{6}{|c|}{ Revised RS-PM model } & \multicolumn{4}{|c|}{ Revised EC-LUE model } \\
\hline & $\mathrm{ET}_{\mathrm{o}}^{\mathrm{a}}$ & $\mathrm{ET}_{\mathrm{p}}{ }^{\mathrm{b}}$ & $R^{2}$ & $\mathrm{PE}$ & RPE & $\mathrm{GPP}_{\mathrm{o}}^{\mathrm{c}}$ & $\mathrm{GPP}_{\mathrm{p}}{ }^{\mathrm{d}}$ & $R^{2}$ & $\mathrm{PE}$ & RPE \\
\hline \multicolumn{11}{|l|}{ Calibration sites } \\
\hline Aspen & 1.81 & 2.58 & 0.84 & 0.75 & 0.41 & 3.23 & 3.22 & 0.83 & -0.01 & 0.00 \\
\hline Burn87 & 2.03 & 2.01 & 0.89 & -0.03 & -0.01 & 1.79 & 1.83 & 0.80 & 0.04 & 0.02 \\
\hline Chestnut & 2.78 & 3.14 & 0.93 & 0.35 & 0.13 & 3.50 & 4.02 & 0.90 & 0.52 & 0.13 \\
\hline Goodwincreek & 4.69 & 4.64 & 0.85 & -0.04 & -0.01 & 3.99 & 4.48 & 0.71 & 0.49 & 0.11 \\
\hline Toledo & 4.86 & 4.87 & 0.83 & 0.01 & 0.00 & 5.63 & 5.69 & 0.78 & 0.06 & 0.01 \\
\hline Willowcreek & 2.60 & 2.79 & 0.81 & 0.19 & 0.07 & 4.88 & 4.12 & 0.76 & -0.76 & -0.18 \\
\hline Puechabon & 3.15 & 2.97 & 0.74 & -0.17 & -0.05 & 3.76 & 2.88 & 0.40 & -0.88 & -0.31 \\
\hline Blackspruce & 1.80 & 2.10 & 0.87 & 0.31 & 0.17 & 2.37 & 2.07 & 0.82 & -0.30 & -0.14 \\
\hline Boeas_nsa & 1.84 & 1.92 & 0.83 & 0.08 & 0.04 & 2.46 & 1.92 & 0.86 & -0.54 & -0.28 \\
\hline Dukepine & 4.82 & 4.57 & 0.79 & -0.25 & -0.05 & 5.24 & 4.79 & 0.75 & -0.45 & -0.09 \\
\hline Howland & 2.77 & 3.04 & 0.86 & 0.28 & 0.10 & 4.29 & 4.57 & 0.88 & 0.28 & 0.06 \\
\hline Jackpine & 1.72 & 2.25 & 0.67 & 0.52 & 0.30 & 2.07 & 2.35 & 0.84 & 0.28 & 0.12 \\
\hline Tharandt & 3.09 & 2.70 & 0.80 & -0.39 & -0.13 & 5.12 & 3.64 & 0.83 & -1.48 & -0.41 \\
\hline Uci1964 & 1.76 & 1.75 & 0.84 & -0.01 & 0.00 & 1.66 & 1.82 & 0.84 & 0.16 & 0.09 \\
\hline Uci1989 & 1.79 & 2.00 & 0.83 & 0.21 & 0.12 & 1.25 & 2.50 & 0.72 & 1.25 & 0.50 \\
\hline Windriver & 3.42 & 3.20 & 0.74 & -0.23 & -0.07 & 3.67 & 3.50 & 0.57 & -0.17 & -0.05 \\
\hline Dukegrass & 4.13 & 4.09 & 0.74 & -0.04 & -0.01 & 3.07 & 2.18 & 0.74 & -0.89 & -0.41 \\
\hline Walnutriver & 3.77 & 3.56 & 0.86 & -0.21 & -0.06 & 2.78 & 2.64 & 0.90 & -0.14 & -0.05 \\
\hline Lavarone & 3.41 & 2.47 & 0.74 & -0.94 & -0.28 & 5.05 & 3.31 & 0.72 & -1.74 & -0.52 \\
\hline Sylvania & 2.27 & 2.66 & 0.87 & 0.40 & 0.17 & 3.34 & 3.96 & 0.90 & 0.62 & 0.16 \\
\hline Winmahard & 4.65 & 4.43 & 0.81 & -0.22 & -0.05 & 5.91 & 4.81 & 0.88 & -1.10 & -0.23 \\
\hline \multicolumn{11}{|l|}{ Validation sites } \\
\hline Bondville & 3.82 & 2.63 & 0.68 & -1.19 & -0.31 & 2.81 & 1.73 & 0.67 & -0.92 & -0.35 \\
\hline Meadirrigated & 3.95 & 3.30 & 0.87 & -0.64 & -0.16 & 5.26 & 3.52 & 0.84 & -1.74 & -0.33 \\
\hline Meadirrrotate & 4.00 & 3.31 & 0.82 & -0.69 & -0.17 & 4.06 & 3.21 & 0.82 & -0.85 & -0.21 \\
\hline Meadrainfed & 3.95 & 3.47 & 0.79 & -0.48 & -0.12 & 4.31 & 3.55 & 0.74 & -0.76 & -0.18 \\
\hline Dukehardwood & 4.33 & 4.42 & 0.85 & 0.08 & 0.02 & 4.15 & 4.58 & 0.77 & 0.43 & 0.10 \\
\hline Hainich & 2.23 & 2.55 & 0.82 & 0.32 & 0.14 & 4.94 & 3.93 & 0.85 & -1.01 & -0.20 \\
\hline Hesse & 2.78 & 2.53 & 0.87 & -0.25 & -0.09 & 5.37 & 2.73 & 0.71 & -2.64 & -0.49 \\
\hline Indianammsf & 4.03 & 3.77 & 0.76 & -0.26 & -0.06 & 5.49 & 5.05 & 0.59 & -0.44 & -0.08 \\
\hline Walkerbrach & 5.11 & 4.63 & 0.73 & -0.48 & -0.09 & 4.90 & 5.95 & 0.41 & 0.96 & 0.19 \\
\hline ParcoTicino & 3.90 & 3.51 & 0.88 & -0.39 & -0.10 & 4.50 & 2.51 & 0.91 & -1.99 & -0.44 \\
\hline Austincary & 3.54 & 4.27 & 0.69 & 0.74 & 0.21 & 4.21 & 5.14 & 0.56 & 0.92 & 0.22 \\
\hline Blackhill & 3.35 & 2.44 & 0.67 & -0.90 & -0.27 & 2.22 & 1.59 & 0.64 & -0.63 & -0.28 \\
\hline Blodgett & 3.17 & 3.65 & 0.73 & 0.48 & 0.15 & 3.25 & 3.50 & 0.61 & 0.24 & 0.08 \\
\hline Control & 2.35 & 2.49 & 0.75 & 0.14 & 0.06 & 1.94 & 1.64 & 0.68 & -0.30 & -0.16 \\
\hline Donaldson & 5.85 & 4.91 & 0.42 & -0.93 & -0.16 & 6.93 & 5.88 & 0.42 & -1.05 & -0.15 \\
\hline LeBray & 4.67 & 3.32 & 0.68 & -1.35 & -0.29 & 6.20 & 3.87 & 0.65 & -2.37 & -0.38 \\
\hline Metoliusmidpine & 2.82 & 3.39 & 0.50 & 0.57 & 0.20 & 3.89 & 3.36 & 0.69 & -0.53 & -0.14 \\
\hline Metoliusoldyoung & 2.52 & 3.09 & 0.68 & 0.57 & 0.23 & 2.23 & 2.56 & 0.69 & 0.34 & 0.15 \\
\hline Niwotridge & 3.39 & 2.96 & 0.81 & -0.43 & -0.13 & 2.10 & 2.26 & 0.70 & 0.16 & 0.08 \\
\hline Uci1930 & 2.03 & 2.21 & 0.82 & 0.18 & 0.09 & 1.54 & 2.40 & 0.67 & 0.93 & 0.63 \\
\hline Uci1981 & 2.85 & 2.57 & 0.84 & -0.28 & -0.10 & 1.20 & 1.28 & 0.61 & 0.09 & 0.08 \\
\hline Uci1998 & 1.80 & 1.38 & 0.91 & -0.42 & -0.23 & 1.12 & 1.48 & 0.83 & 0.46 & 0.45 \\
\hline Wetzstein & 2.79 & 2.28 & 0.75 & -0.51 & -0.18 & 4.45 & 2.89 & 0.82 & -1.56 & -0.35 \\
\hline Winmared & 5.39 & 5.54 & 0.43 & 0.16 & 0.03 & 6.19 & 5.52 & 0.68 & -0.75 & -0.12 \\
\hline Burn99 & 2.19 & 2.30 & 0.73 & 0.11 & 0.05 & 1.02 & 1.65 & 0.67 & 0.63 & 0.62 \\
\hline Canaanvalley & 5.23 & 3.28 & 0.20 & -1.95 & -0.37 & 3.53 & 4.01 & 0.52 & 0.49 & 0.14 \\
\hline Lethbridge & 1.90 & 1.84 & 0.59 & -0.06 & -0.03 & 0.92 & 0.53 & 0.28 & -0.39 & -0.43 \\
\hline Monte Bondone & 3.37 & 2.04 & 0.91 & -1.33 & -0.39 & 3.67 & 2.11 & 0.80 & -1.55 & -0.42 \\
\hline Vairaranch & 2.25 & 2.09 & 0.51 & -0.16 & -0.07 & 2.97 & 2.94 & 0.55 & -0.07 & -0.02 \\
\hline Fortdix & 3.14 & 2.60 & 0.78 & -0.59 & -0.18 & 1.76 & 2.73 & 0.86 & 0.97 & 0.55 \\
\hline Nonantola & 2.99 & 2.52 & 0.54 & -0.47 & -0.16 & 4.61 & 2.52 & 0.47 & -2.09 & -0.45 \\
\hline Umichigan & 3.60 & 3.19 & 0.86 & -0.41 & -0.11 & 4.73 & 5.96 & 0.78 & 1.12 & 0.23 \\
\hline Tonzi Ranch & 1.15 & 2.21 & 0.57 & 1.06 & 0.93 & 1.11 & 2.09 & 0.80 & 0.98 & 0.89 \\
\hline
\end{tabular}

a Observed ET from eddy covariance measurements.

b Predicted ET by the revised RS-PM model.

c Observed GPP from eddy covariance measurements.

d Predicted GPP by the revised EC-LUE model.

of GPP simulations in the some study sites. For example, overestimates of ET at Tonzi Ranch induced overestimates of GPP.

Four cropland sites were included in this study for testing the performance of EC-LUE at cropland ecosystems. These four sites were characterized by different ecosystem features: (a) irrigated continuous maize (Meadirrigated), (b) irrigated maize-soybean rotation (Bondville and Meadirrotate), and (c) rainfed maize-soybean rotation (Meadrainfed). The EC-LUE model performed very well for predicting the soybean ecosystem, but significantly underestimated the GPP for maize. There was similar model performance in irrigated and rain fed ecosystems.

We compared the annual mean GPP observations measured at the flux towers and two sets of estimated GPP with the revised EC-LUE driven by tower-specific meteorology (Fig. 8a) and the global MERRA meteorology (Fig. 8b), respectively. The coefficient of determination between the GPP observations and the tower-driven algorithm estimates was 0.81 with a slight underestimate of GPP (Fig. 8a). The model explained $67 \%$ of the variations of GPP using MERRA dataset, 


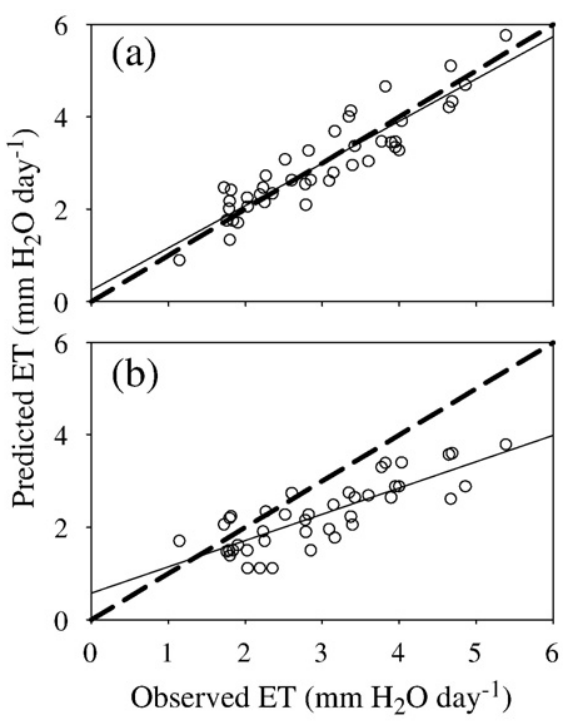

Fig. 4. Comparison of annual mean evapotranspiration (ET) observations from the flux tower sites and estimated by the revised RS-PM model. These data were created using (a) tower-specific meteorology $\left(y=0.91 x+0.24, R^{2}=0.83\right)$ and (b) the global MERRA meteorology $\left(y=0.57 x+0.57, R^{2}=0.67\right)$

and significantly underestimated GPP across the spatial scales (Fig. 8b).

\subsection{Global spatial patterns of ET and GPP}

We assessed the global spatial patterns of ET and GPP averaged from 2000 to 2003 using $0.5^{\circ} \times 0.6^{\circ}$ monthly gridded MERRA input data. ET was high over the tropical rain forests and subtropical forest regions like the southeastern United States and the Pantanal region of South American. ET was low over deserts, high mountain regions, and the polar zones (Fig. 9). The southern hemispheric tropics remained consistently high, while the major deserts of northern Africa and Australia remain consistently low. Global mean ET estimated by our revised RS-PM model was $417 \pm 38 \mathrm{~mm}_{\text {year }}{ }^{-1}$ across the vegetated area.

Global annual GPP was $110.5 \pm 21.3 \mathrm{Pg}$ C. The highest annual production ( $>2000 \mathrm{~g} \mathrm{C} \mathrm{m}^{-2}$ ) is found in the humid tropics (Amazonia, Central Africa, South-east Asia), where both temperature and moisture requirements are fully satisfied for photosynthesis. Temperate regions have an intermediate GPP $\left(1000-1400 \mathrm{~g} \mathrm{C} \mathrm{m}^{-2}\right)$, and the lowest GPP $\left(<400 \mathrm{~g} \mathrm{C} \mathrm{m}^{-2}\right)$ is found in both cold and arid regions, where either temperature or precipitation are limiting factors (Fig. 10).

\section{Discussion}

\subsection{Model performance analysis}

Model calibration and validation at 54 EC sites in North America and Europe suggested that the revised RS-PM and EC-LUE models were robust and reliable across the most of biomes and geographic regions. Fig. 3 showed that the revised RS-PM model did not produce significant predictive errors of ET across the calibration and validation sites (Fig. 3). The EC-LUE model underestimated GPP at the validation sites (Fig. 7b), however, several croplands were included in validation sites, and the EC-LUE model significantly underestimated the GPP for maize. When excluding the data from the four croplands, the performance of EC-LUE model get much better.

Under the same climate conditions, $\mathrm{C}_{4}$ crops have greater photosynthetic capacity and more rapid accumulation of green leaf area than $C_{3}$ crops (Suyker et al., 2005). Parameters of EC-LUE model, however, were calibrated at $C_{3}$ plant dominant ecosystems, which was the major cause for underestimation of GPP at the maize crops. It is worth noting, however, that overestimating magnitude of GPP for maize were close at the four croplands, and peak simulated GPP were $50 \%$ smaller than observed GPP. Consistent potential light use efficiency can be derived for $\mathrm{C}_{4}$ crop to improve the performance of EC-LUE model at the maize croplands. Meadirrigated site was selected to calibrate the EC-LUE model for maize croplands, and the calibrated values for optimal temperature and potential LUE were $19{ }^{\circ} \mathrm{C}$ and $4.06 \mathrm{~g} \mathrm{C} \mathrm{MJ}^{-1}$. The EC-LUE model successfully predicted the magnitudes and seasonal variations of observed GPP at the Meadirrigated site and other three croplands using different parameters value for $\mathrm{C}_{3}$ and $\mathrm{C}_{4}$ crops (Fig. 11). This result implied that it is necessary to use a spatial distribution map of $C_{3}$ and $C_{4}$ crops for improving the accuracy for quantifying GPP across the global scale.

The revised RS-PM and EC-LUE models used satellite data to provide temporally and spatially continuous information over vegetated surfaces, which significantly strengthened model performances across the regional scales. This study used MODIS/Terra NDVI and LAI products, directly downloaded from the MODIS Web site. No attempt was made to improve the quality of the NDVI or LAI data. Therefore, any noise or errors in the satellite data was transferred to ET and GPP predictions. In addition, we used $1-\mathrm{km}^{2}$ MODIS NDVI and LAI pixels for amorphous polygon eddy flux footprints that change throughout the day and year. If the vegetation and environmental characteristics within the footprint are representative of the surrounding area in which the MODIS pixels contain, then the pixel-to-footprint match should be adequate. A forested eddy flux site adjacent to a clear cut, for example, would induce problems if both the forest and clear cut were included in the MODIS overlap. Thus, some error in our model estimates for the eddy flux sites can be attributed to inaccurate NDVI and LAI estimates for the footprints.

In order to strengthen the applicability of EC-LUE at the regional scale, net radiation was used to substitute the summation of $\mathrm{H}$ and LE for representing the downward-regulation scalars for the effect of moisture on LUE of vegetation. However, we reasoned that soil heat flux $\left(G_{\mathrm{s}}\right)$ has high spatial variability mismatching with the $R_{\mathrm{n}}$ and $(\mathrm{H}+\mathrm{LE})$ measurement, which resulted in prediction errors of modeling GPP. Clearly, the uncertainty in the $G_{s}$ is large because of the spatial variability of vegetation and soil (Mayocchi \& Bristow, 1995; Twine et al., 2000). In grasslands and other ecosystems with sparse canopies, $G_{s}$ plays a more critical role in the energy fluxes. For example, Meyers (2001) found in grasslands that $G_{\mathrm{s}}$ accounted for $25 \%$ of $R_{\mathrm{n}}$. In forests, however, $G_{\mathrm{s}}$ usually accounts for $<5 \%$ of $R_{\mathrm{n}}$ (Beringer et al., 2005; Chen et al., 2002), and can be neglected. Estimation of $G_{\mathrm{s}}$ across the regional scales will improve the accuracy for quantifying GPP at large regions.

Significant underestimation of GPP was found at several European sites (e.g., Hesse, MonteBondone, Nonantola) (Fig. 3). Recent studies found increased fraction of diffuse radiation results in higher light use efficiencies of plant canopies (Alton et al., 2007; Gu et al., 2003) because increases in the blue/red light ratio may lead to higher photosynthesis rates per unit leaf area with diffuse radiation (Urban et al., 2007). Our results showed significantly higher proportion of cloudy days (the ratio of gross radiation at the top of the canopy with its top-of-atmosphere is less than 0.5 ) in Europe ( $32 \pm 7 \%$ ) compared with American and Asian sites (14 $\pm 9 \%$ ), which was likely a major cause for underestimation of GPP at several European sites.

The EC-LUE model obviously overestimated GPP at several high latitude sites: Burn99, Uci1930, Uci1981, Uci1989 and Uci1998. For example, predicted GPP was higher than estimated GPP at Burn99 with PE values being $0.7 \mathrm{~g} \mathrm{C} \mathrm{m}^{-2} \mathrm{day}^{-1}$ and RPE values were $69 \%$, respectively (Table 2 ). Mosses probably play an important role for quantifying GPP at the northern regions. Mosses are an important component of ecosystem at the high latitude regions, where they 

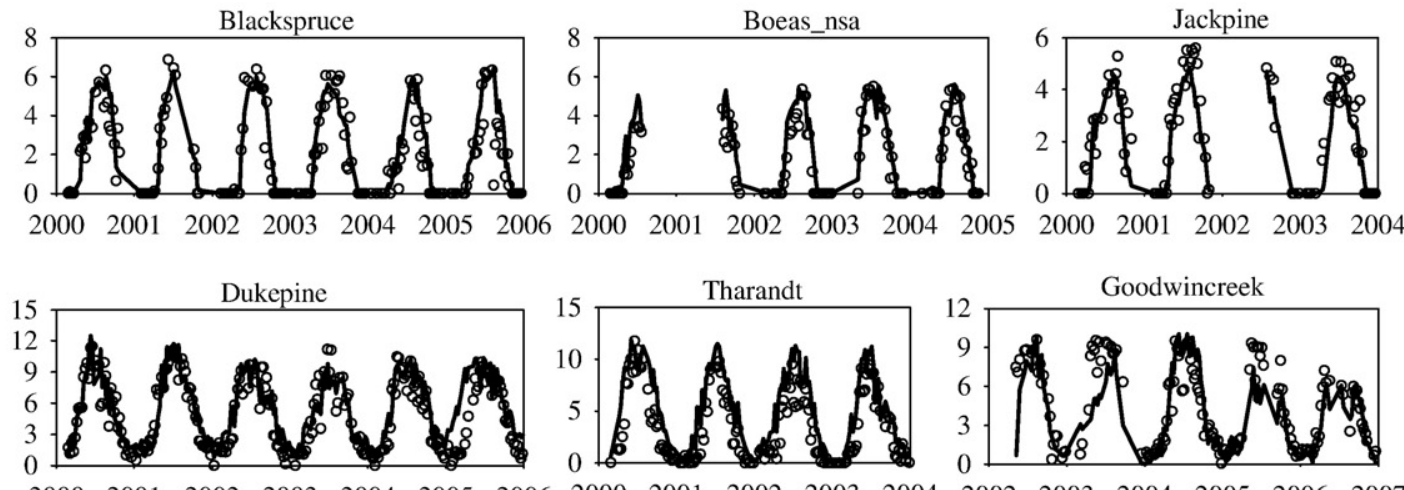

$\begin{array}{llllllllllllllllll}2000 & 2001 & 2002 & 2003 & 2004 & 2005 & 2006 & 2000 & 2001 & 2002 & 2003 & 2004 & 2002 & 2003 & 2004 & 2005 & 2006 & 2007\end{array}$
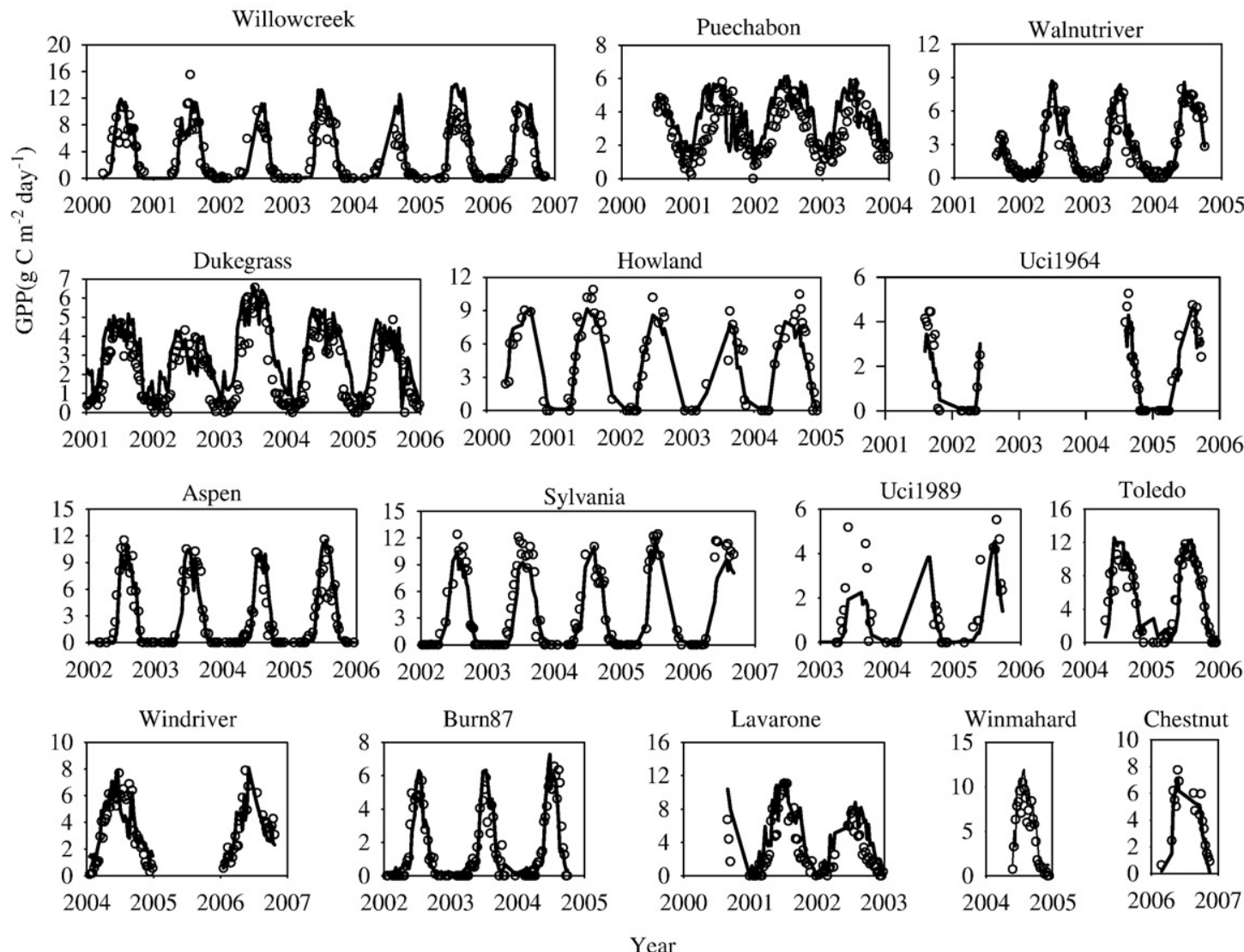

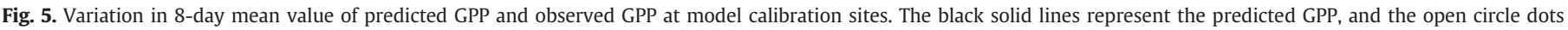
represent observed GPP.

often dominate the ground cover. For example, at Burn99 site, in $2002,30 \%$ of the surface was covered by grasses and deciduous shrubs, and the remaining $70 \%$ of the surface was covered by moss (Liu \& Randerson, 2008). The northern ecosystems are relatively open, due to the narrow canopy and low density of trees, which makes mosses an important contributor to the NDVI signal. On the other hand, mosses are fundamentally different from vascular plants with respect to vegetation production. Field experiments showed significantly low light use efficiency in mosses, ranging from 10 to $50 \%$ of that found in vascular plants (Whitehead \& Gower, 2001). Therefore, high distribution and low photosynthetically capacity of mosses resulted in a significant overestimation of GPP at the high latitude ecosystems. Further improvement of the light use efficiency model needs to consider the function of mosses across the entire northern ecosystems.

\subsection{Global estimates of ET and GPP}

Although global validation of ET or GPP is problematic, we are able to investigate its reliability by comparison with other global models from the literature. Our estimate of annual global mean ET was $417 \mathrm{~mm}$ year $^{-1}$, which was comparable to other estimations. The comparison of 15-model simulation from the Global Soil Wetness Project-2 (GSWP-2; Dirmeyer et al., 2006) suggested that the annual ET ranges from 272 to $441 \mathrm{~mm}$ year $^{-1}$. A global evapotranspiration estimation of ET by Fisher et al. (2008) showed 444 mm year $^{-1}$ using globally consistent datasets from the International Satellite LandSurface Climatology Project, Initiative II (ISLSCP-II) and the Advanced Very High Resolution Spectroradiometer (AVHRR).

The global magnitude of GPP agreed, in general, with results obtained by an increasing number of models (Cramer et al., 1999; 

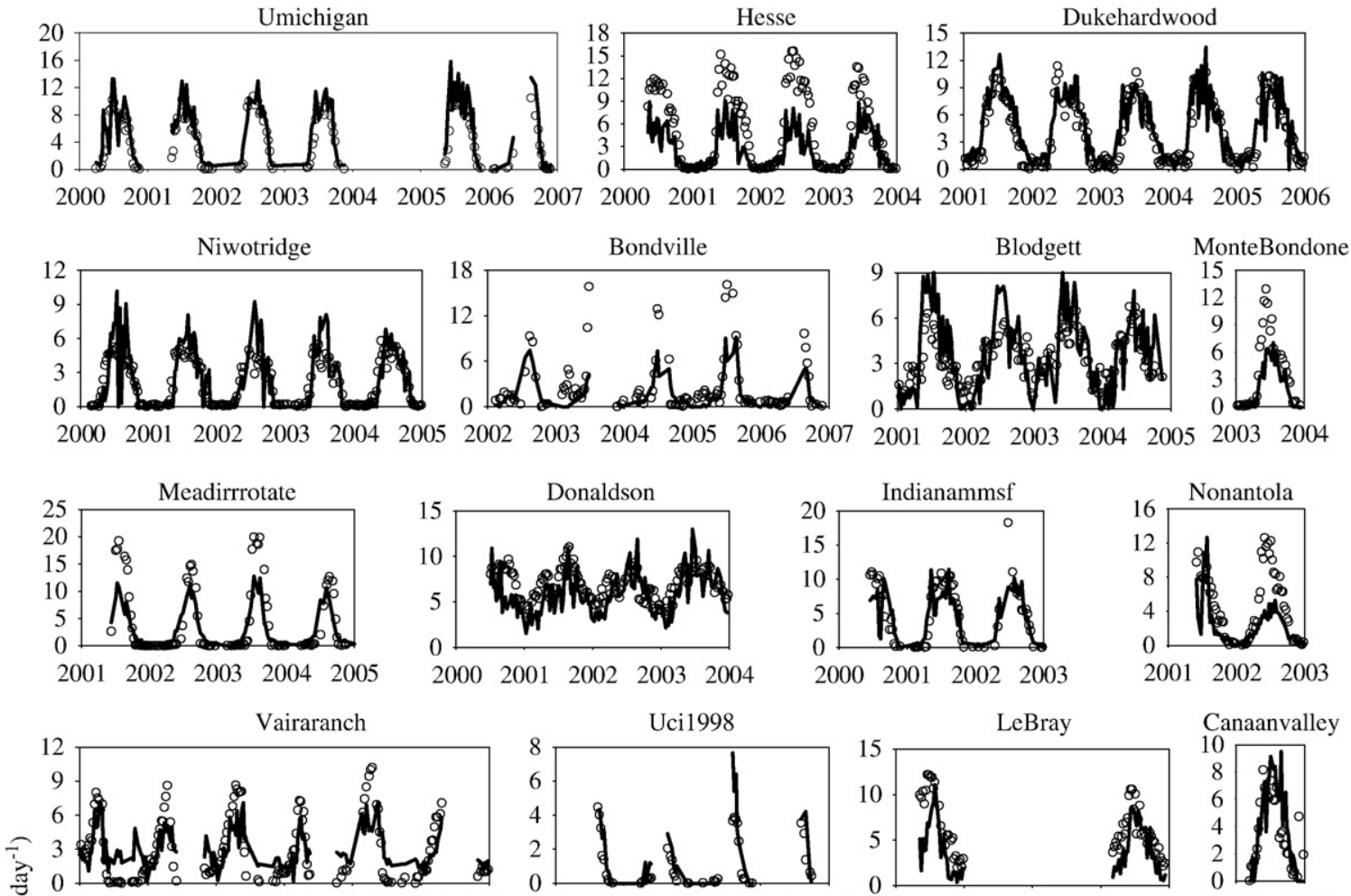

Canaanvalley
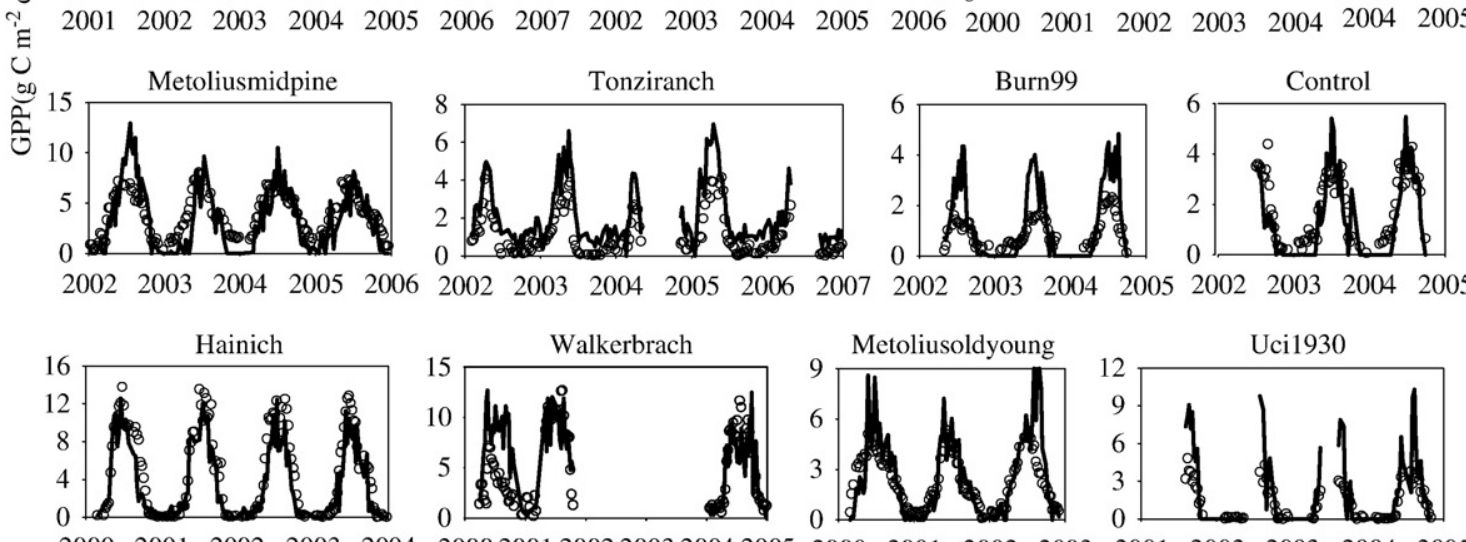

20002001200220032004200020012002200320042005200020012002200320012002200320042005
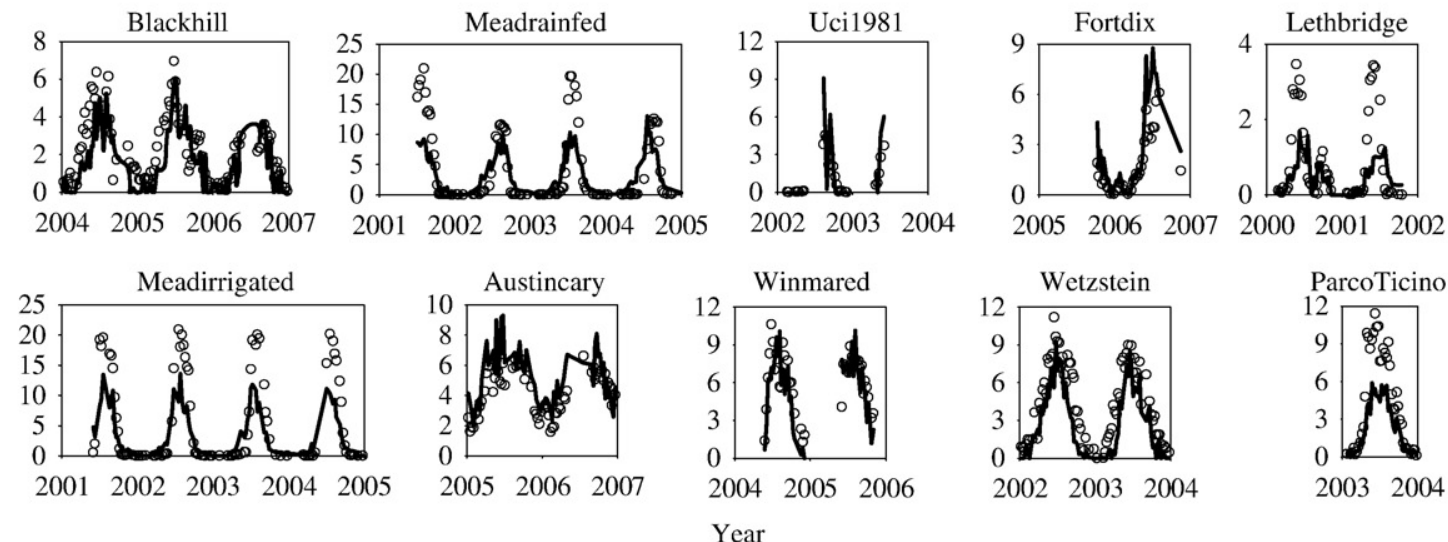

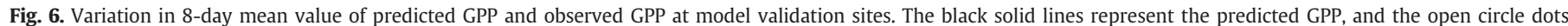
represent observed GPP.

Goetz et al., 2000). Comparison of 16 global NPP models showed a range of global NPP from 39.9 to $80 \mathrm{PgC} \mathrm{m}^{-2}$ year $^{-1}$ with a mean of 54.9 $\mathrm{Pg} \mathrm{C} \mathrm{m}^{-2}$ year $^{-1}$ (Cramer et al., 1999). The EC-LUE model estimated global GPP at $110.5 \mathrm{PgC}$ year $^{-1}$, which falls in the range of Cramer's representation ( 0.5 as ratio of NPP and GPP). The MODIS-GPP product (MOD17A) estimates global GPP at $113 \mathrm{Pg}$ C. Fig. 12 showed 


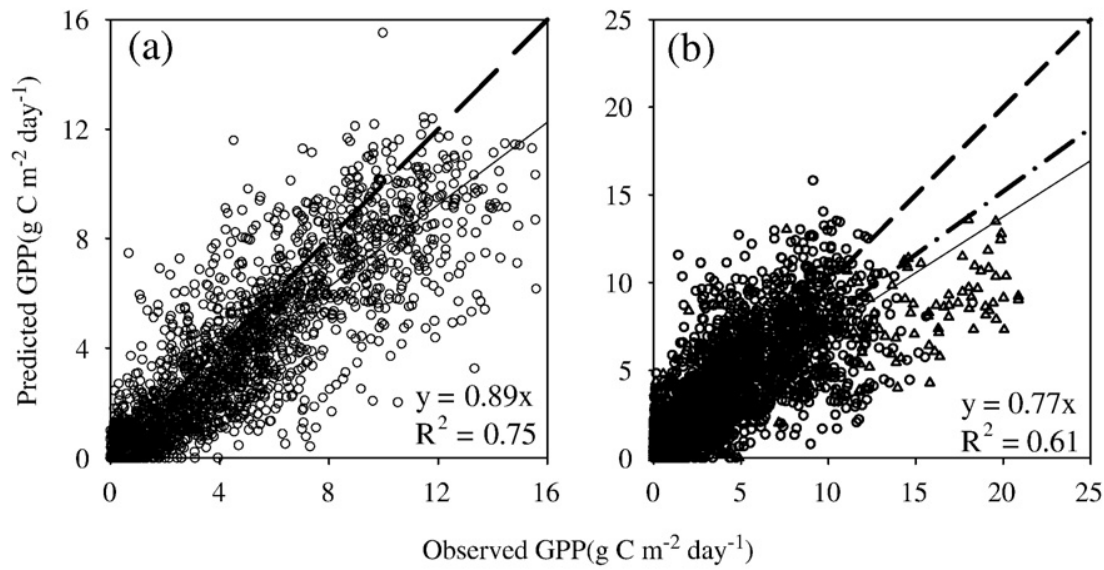

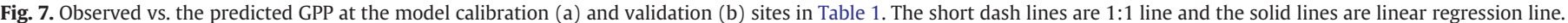
Triangles in $\mathrm{b}$ indicate the data of four cropland sites, and short-dot-dot line is linear regression line after excluding the data of four cropland sites $\left(y=0.84 x, R^{2}=0.62\right)$.

these estimates aggregated for vegetation types. On a biome basis, the EC-LUE model had good agreement in its representation of MODIS-GPP.

The accuracy of global estimates in ET and GPP are highly dependent on the global meteorology dataset. The accuracy of the existing meteorological reanalysis data sets showed marked differences both spatially and temporally. Zhao et al. (2006) compared surface meteorological datasets from three well-documented global reanalyses: DAO (NASA Data Assimilation Office), ECMWF (European Centre for Medium-Range Weather Forecasts), and NCEP/NCAR (National Centers for Environmental Prediction/National Center for Atmospheric Research reanalysis) with observed weather station data. The results showed NCEP tends to overestimate surface solar radiation, and underestimate both temperature and vapor pressure deficit (VPD). ECMWF has the highest accuracy, but its radiation is lower in tropical regions, and the accuracy of DAO lies between NCEP and ECMWF. Global MODIS-GPP driven by DAO, ECMWF, and NCEP displayed notable differences ( $>20 \mathrm{Pg} \mathrm{C} \mathrm{m}^{-2}$ year $^{-1}$ ). In this study, MERRA tended to underestimate surface net radiation (Fig. 13), which resulted in lower predicted ET and GPP. Our results revealed that the

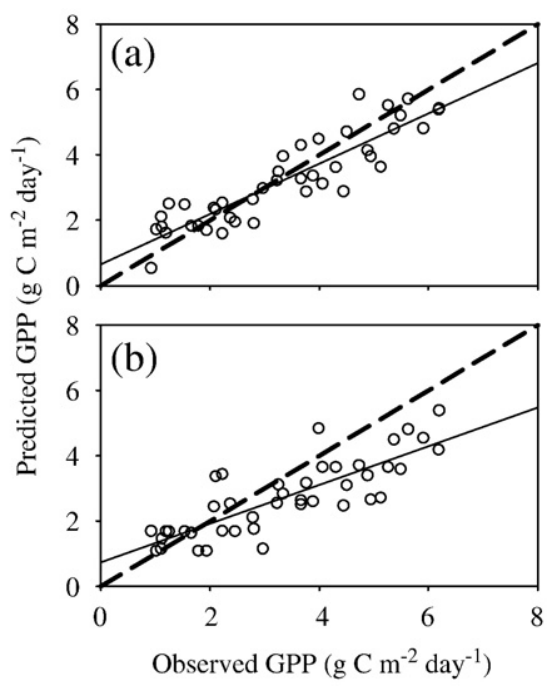

Fig. 8. Comparison of annual mean GPP observations from the flux tower sites and the ET estimates by the revised EC-LUE model. These data were created using (a) towerspecific meteorology $\left(y=0.77 x+0.64, R^{2}=0.81\right)$ and (b) the global MERRA meteorology $\left(y=0.59 x+0.73, R^{2}=0.67\right)$. biases in meteorological reanalysis can introduce substantial errors into GPP and ET estimations, and emphasize the need to minimize these biases to improve the quality of GPP and ET products. In addition, due to the complex terrain and resulting heterogeneity of the landscape surrounding flux towers, model biases resulted in part by upscaling from flux tower to the larger $0.5^{\circ} \times 0.6^{\circ}$ area. The comparison of observed ET or GPP with the estimated using MERRA dataset across all 54 sites may introduce uncertainties due to the differences in tower footprints and under varying environmental conditions for a given tower.

\subsection{Model advantages and limitations}

A broad range of models exist now, and they are being used to investigate the magnitude and geographical distributions of carbon and water fluxes at a global scale (Brisson et al., 1998; Foley et al., 1996; Potter et al., 1993; Running et al., 2000). Many models are now being compared to detailed biophysical measurements obtained at individual field sites. However, for global- and regional-scale ecosystem models, it is necessary to make these comparisons at various geographical regions for accurate quantification of temporal and spatial variations in vegetation production (Delire \& Foley, 1999). In this study, 54 eddy covariance towers were included to calibrate and validate the models, which confirmed the accuracy and applicability of the EC-LUE and revised RS-PM models across wide range of climate and ecosystem types.

Parameterization is critical for global simulation of carbon and water fluxes, and directly determines the model performance. For example, although PLAI (Potsdam Land Atmosphere Interaction Model, Plöchl \& Cramer, 1995) uses the same functional formulations for simulating vegetation production as FBM (Frankfurt Biosphere Model, Kindermann et al., 1993), the seasonal and spatial distribution of vegetation production estimated by PLAI is different from FBM due to differences in parameterization and vegetation classification schemes (Kicklighter et al., 1999). However, regional parameterization of ecosystem models probably presents the most difficult task for estimating water and carbon fluxes. The light use efficiency (LUE) model may have the most potential to successfully solve the problems because of its theoretical basis (Running et al., 2000). Potential light use efficiencies in light use efficiency models are theoretically consistent in various vegetation types (Monteith, 1972, 1977), except the difference between $C_{4}$ and $C_{3}$ vegetation types. Most light use efficiency models, however, did not achieve this assumption because they failed to develop the uniform environmental constraint equations to LUE among the various ecosystems. The EC-LUE model 


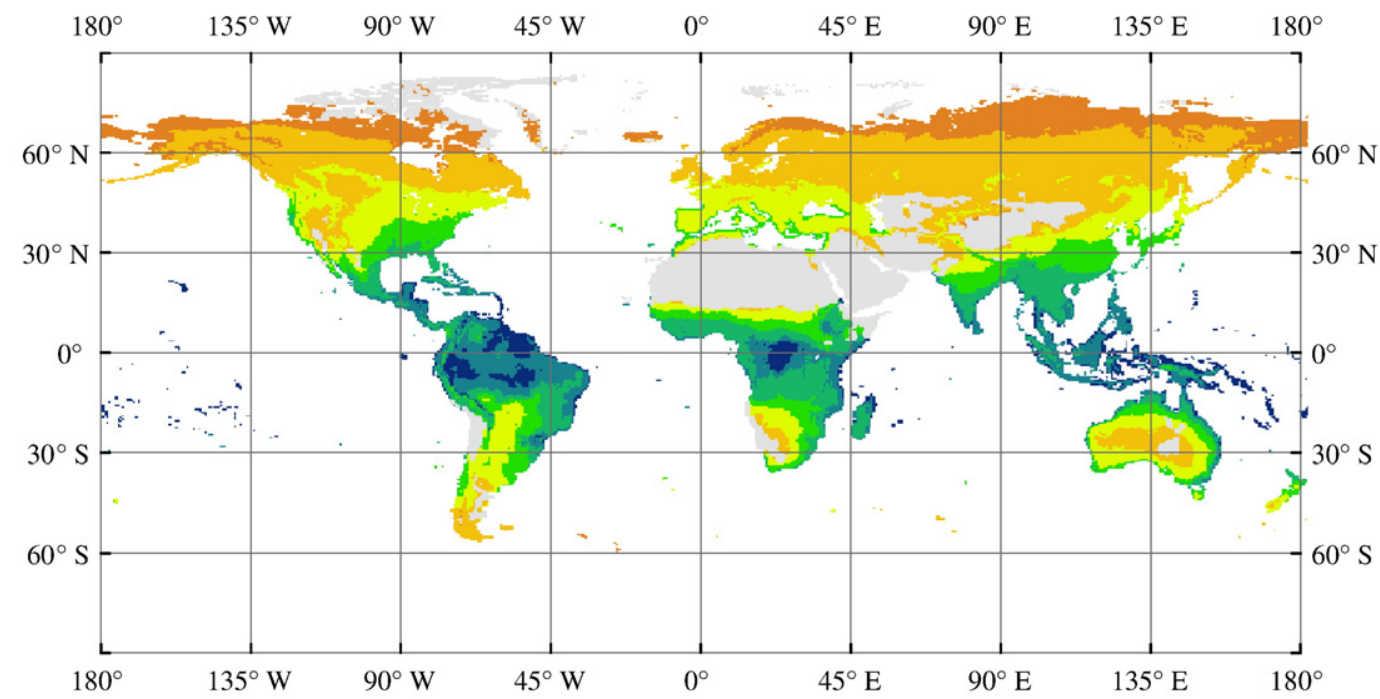

$\mathrm{ET}\left(\mathrm{mm} \mathrm{H}_{2} \mathrm{O} \mathrm{y}^{-1}\right)$

\begin{tabular}{|c|c|c|c|}
\hline No data & $150-300$ & $450-600$ & $750-900$ \\
\hline $0-150$ & $300-450$ & $600-750$ & $900-1,236$ \\
\hline
\end{tabular}

Fig. 9. Global evapotranspiration (ET) driven by interpolated $0.5^{\circ} \times 0.6^{\circ}$ MERRA meteorological data and MODIS data averaged from 2000 to 2003 .

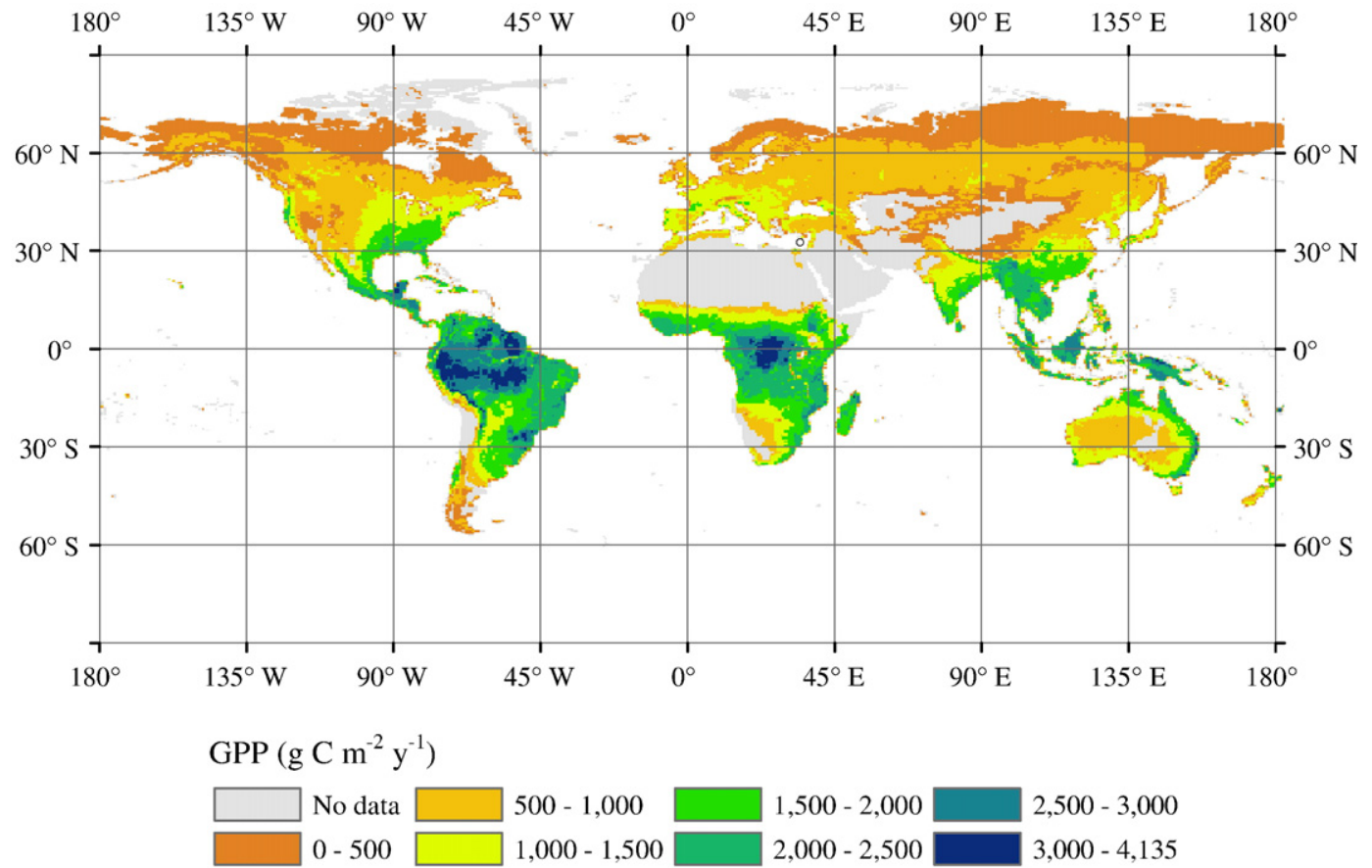

Fig. 10. Global GPP driven by interpolated $0.5^{\circ} \times 0.6^{\circ}$ MERRA meteorological data and MODIS data averaged from 2000 to 2003 .

successfully generated invariant potential light use efficiency with vegetation types by using the general water and temperature constrains equations to downscale potential light use efficiency. Uniform model parameters of the EC-LUE model across the various ecosystem types and geographical regions produced many benefits to map GPP over large areas with high accuracy and applicability avoiding regional model parameterization.

The EC-LUE and revised RS-PM models based on remote sensing data have a relatively strong potential to analyze temporal changes. Without additional algorithms for simulating changes in NDVI under altered conditions, however, these two models have limited use for climate- or vegetation-change scenarios. Extensions and improvements in the satellite record will serve to enhance remote sensing's usefulness for detecting and quantifying global change.

\section{Acknowledgements}

We acknowledge the financial support from National Key Basic Research and Development Plan of China (2010CB800504 and 2009AA122101) and the Global Modeling and Assimilation Office. 


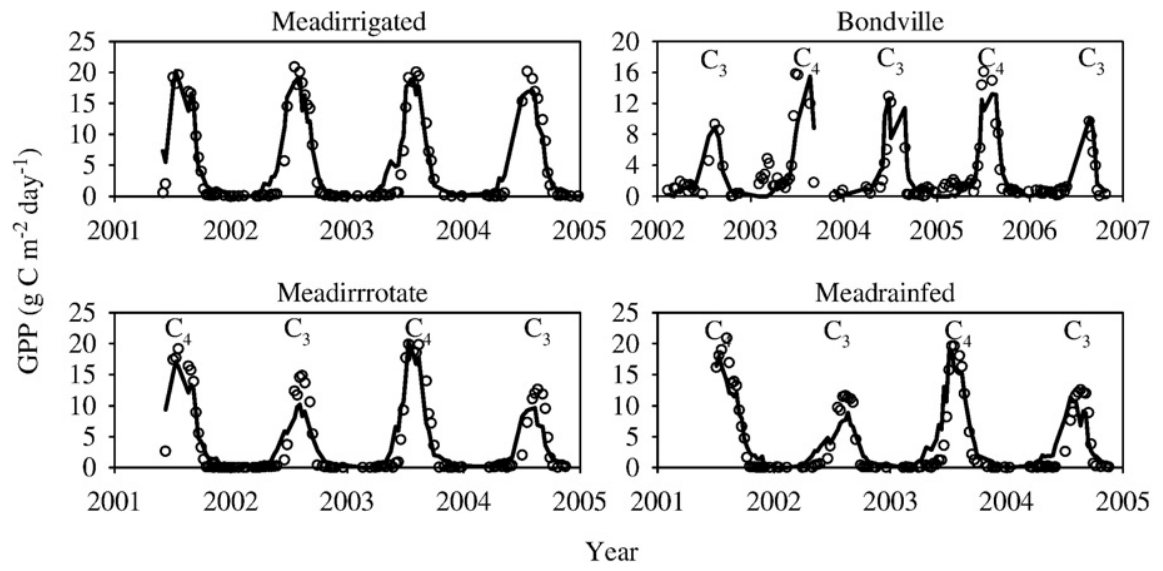

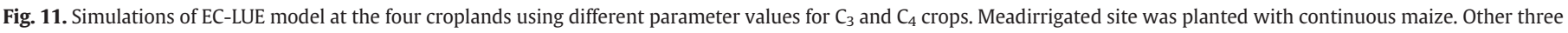
sites were planted with maize-soybean rotation, and " $\mathrm{C}_{3}$ " and " $\mathrm{C}_{4}$ " were used to indicate maize and soybean crops respectively.

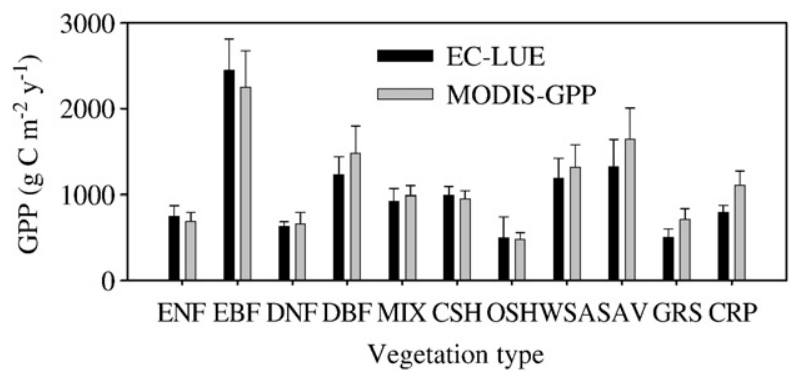

Fig. 12. Comparison of EC-LUE and MODIS-GPP product at the various ecosystem types. ENF: evergreen needleleaf forest; EBF: evergreen broadleaf forest; DNF: deciduous needleleaf forest; DBF: deciduous broadleaf forest; MIX: mixed forest of DBF and ENF; CSH: closed shrubland; OSH: open shrubland; WSA: woody savanna; SAV: savanna; GRS: grassland; CRP: cropland.

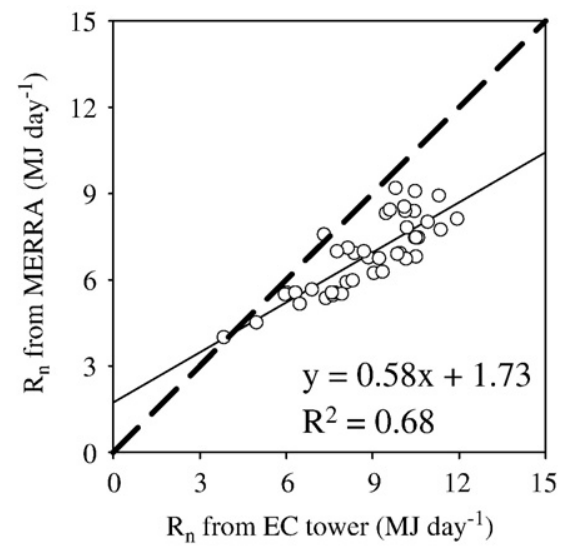

Fig. 13. Correlation of net radiaton $\left(R_{\mathrm{n}}\right)$ between EC tower and MERRA dataset.

\section{References}

Alton, P. B., North, P. R., \& Los, S. O. (2007). The impact of diffuse sunlight on canopy light-use efficiency gross photosynthetic product and net ecosystem exchange in three forest biomes. Global Change Biology, 13, 1-12.

Anthoni, P. M., Knohl, A., Rebmann, C., Freibauer, A., Mund, M., Ziegler, W., et al. (2004). Forest and agricultural land-use-dependent $\mathrm{CO}_{2}$ exchange in Thuringia, Germany. Global Change Biology, 10, 2005-2019.

Baldocchi, D. D., Valentini, R., Running, S. R., Oechel, W., \& Dahlman, R. (1996). Strategies for measuring and modelling $\mathrm{CO}_{2}$ and water vapor fluxes over terrestrial ecosystems. Global Change Biology, 2, 159-168.

Battle, M., Fletcher, S. M., Bender, M. L., Keeling, R. F., Manning, A. C., Gruber, N., et al. (2006). Atmospheric potential oxygen: New observations and their implications for some atmospheric and oceanic models.Global Biogeochemical Cycles, 20 B10101-B1010-15.

Berbigier, P., Bonnefond, J. M., \& Mellmann, P. (2001). $\mathrm{CO}_{2}$ and water vapour fluxes for 2 years above Euroflux forest site. Agricultural and Forest Meteorology, 108, $183-197$.

Beringer, J., Chapin, F. S., Thompson, C. C. \& McGuire, A. D. (2005). Surface energy exchanges along a tundra-forest transition and feedbacks to climate. Agricultural and Forest Meteorology, 131, 143-161.

Betts, A. K., \& Ball, J. H. (1997). Albedo over the boreal forest. Journal Geophysical Research, 102, 28,901-28,909.

Bousquet, P., Peylin, P., Ciais, P., LeQuere, C., Friedlingstein, P., \& Tans, P. (2000). Regional changes in carbon dioxide fluxes of land and oceans since 1980. Science, $290,1342-1346$

Brisson, N., Itier, B., L'Hotel, J. C., \& Lorendeau, J. Y. (1998). Parameterization of the Shuttleworth-Wallace model to estimate daily maximum transpiration for use in crop models. Ecological Modelling, 107, 159-169.

Canadell, J. G., Pataki, D., Gifford, R., Houghton, R., Luo, Y., Raupach, M., et al. (2007). Saturation of the terrestrial carbon sink. In J. G. Canadell, D. Pataki, \& L. Pitelka (Eds.), Terrestrial ecosystems in a changing worldIGBP Series. (pp. 81-100) Berlin: Springer.

Cao, M. K., \& Woodward, F. I. (1998). Net primary and ecosystem production and carbon stocks of terrestrial ecosystems and their responses to climate change. Global Change Biology, 4, 185-198.

Chen, J. Q., Falk, M., Euskirchen, E., Paw, K. T. U., Suchanek, T. H., Ustin, S. L., et al. (2002). Biophysical controls of carbon flows in three successional Douglas-fir stands based on eddy-covariance measurements. Tree Physiology, 22, 169-177.

Cleugh, H. A., Leuning, R., Mu, Q., \& Running, S. W. (2007). Regional evaporation estimates from flux tower and MODIS satellite data. Remote Sensing of Environment, 106, 285-304.

Cook, B. D., Davis, K. J., Wang, W., Desai, A. R., Berger, B. W., Teclaw, R. M., et al. (2004). Carbon exchange and venting anomalies in an upland deciduous forest in northern Wisconsin, USA. Agricultural and Forest Meteorology, 126, 271-295.

Cramer, W., Bondeau, A., Moore, B., Churkina, C., Nemry, B., Ruimy, A., et al. (1999). Comparing global models of terrestrial net primary productivity (NPP): Overview and key results. Global Change Biology, 5, 1-15.

Curtis, P. S., Vogel, C. S., Gough, C. M., Schmid, H. P., Su, H. B., \& Bovard, B. D. (2005). Respiratory carbon losses and the carbon use efficiency of a northern hardwood forest, 1999-2003. New Phytologist, 167, 437-456.

Delire, C., \& Foley, J. A. (1999). Evaluating the performance of a land surface/ecosystem model with biophysical measurements from contrasting environments. Journal of Geophysical Research, 104, 16,895-16,909.

Desai, A. R., Bolstad, P. V., Cook, B. D., Davis, K. J., \& Carey, E. V. (2005). Comparing net ecosystem exchange of carbon dioxide between an old-growth and mature forest in the upper Midwest, USA. Agricultural and Forest Meteorology, 128, 33-55.

Dirmeyer, P. A. (1994). Vegetation stress as a feedback mechanism in mid-latitude drought. Journal of Climate, 7, 1463-1483.

Dirmeyer, P. A., Gao, X., Zhao, M., Guo, Z., Oki, T., \& Hanasaki, N. (2006). GSWP-2: Multimodel analysis and implications for our perception of the land surface. Bulletin of the American Meteorological Society, 87, 1381-1397.

Dunn, A. L., Barford, C. C., Wofsy, S. C., Goulden, M. L., \& Daube, B. C. (2007). A long-term record of carbon exchange in a boreal black spruce forest: Means, responses to interannual variability, and decadal trends. Global Change Biology, 13, 577-590.

Falge, E., Baldocchi, D., Olson, R., Anthoni, P., Aubinet, M., Bernhofer, C., et al. (2001). Gap filling strategies for defensible annual sums of net ecosystem exchange. Agricultural and Forest Meteorology, 107, 43-69.

Fiora, A., \& Cescatti, A. (2006). Diurnal and seasonal variability in radial distribution of sap flux density: Implications for the estimates of stand transpiration. Tree Physiology, 26, 1217-1225.

Fisher, J. B., Tu, K. P., \& Baldocchi, D. D. (2008). Global estimates of the land-atmosphere water flux based on monthly AVHRR and ISLSCP-II data, validated at 16 FLUXNET sites. Remote Sensing of Environment, 112, 901-919. 
Flanagan, L. B., \& Johnson, B. G. (2005). Interacting effects of temperature, soil moisture and plant biomass production on ecosystem respiration in a northern temperate grassland. Agricultural and Forest Meteorology, 130, 237-253.

Foley, J. A., Prentice, I. C., Ramankutty, N., Levis, S., Pollard, D., Sitch, S., et al. (1996). An integrated biosphere model of land surface processes, terrestrial carbon balance, and vegetation dynamics. Global Biogeochemical Cycles, 10, 603-628.

Foroutan-Pour, K., Dutilleul, P., \& Smith, D. L. (2001). Inclusion of the fractal dimension of leafless plant structure in the Beer-Lambert Law. Agronomy Journal, 93, $333-338$.

Friedl, M. A. (1996). Relationships among remotely sensed data, surface energy balance, and area-averaged fluxes over partially vegetated land surfaces. Journal of Applied Meteorology, 35, 2091-2103.

Friend, A. D., Arneth, A., Kiang, N. Y., Lomas, M., Ogee, J., Rodenbeck, C., et al. (2007). FLUXNET and modelling the global carbon cycle. Global Change Biology, 13, 610-633.

Gash, J. H. C. (1987). An analytical framework for extrapolating evaporation measurements by remote sensing surface temperature. International Journal of Remote Sensing, 8, 1245-1249.

Gholz, H. L., \& Clark, K. L. (2002). Energy exchange across a chronosequence of slash pine forests in Florida. Agricultural and Forest Meteorology, 112, 87-102.

Gholz, H. L., Vogel, S. A., Cropper, W. P., Jr., McKelvey, K., Ewel, K. C., Teskey, R. O., et al. (1991). Dynamics of canopy structure and light interception in Pinus elliottii stands of north Florida. Ecological Monograph, 61, 33-51.

Global Modeling and Assimilation Office (2004). File specification for GEOSDAS gridded output version 5.3, report. Greenbelt, Md: NASA Goddard Space Flight Cent.

Goetz, S. J., Prince, S. D., Small, J., \& Gleason, C. R. (2000). Interannual variability of global terrestrial primary production: Results of a model driven with satellite observations. Journal of Geophysical Research, 105, 20,077-20,091.

Goldstein, A. H., Hultman, N. E., Fracheboud, J. M., Bauer, M. R., Panek, J. A., Xu, M., et al. (2000). Effects of climate variability on the carbon dioxide, water, and sensible heat fluxes above a ponderosa pine plantation in the Sierra Nevada (CA). Agricultural and Forest Meteorology, 101, 113-129.

Goulden, M. L., Winston, G. C., McMillan, A. M. S., Litvak, M. E., Read, E. L., Rocha, A. V. et al. (2006). An eddy covariance mesonet to measure the effect of forest age on land-atmosphere exchange. Global Change Biology, 12, 2146-2162.

Granier, A., Ceschia, C., Damesin, C., Dufrene, E., \& Epron, D. (2000). The carbon balance of a young Beech forest. Functional Ecology, 14, 312-325.

Griffis, T. J., Black, T. A., Morgenstern, K., Barr, A. G., Nesic, Z., Drewitt, G. B., et al. (2003). Ecophysiological controls on the carbon balances of three southern boreal forests. Agricultural and Forest Meteorology, 117, 53-71.

Grünwald, T., \& Berhofer, C. (2007). A decade of carbon, water and energy flux measurements of an old spruce forest at the Anchor Station Tharandt. Tellus, 59B, 387-396.

Gu, L. H., Baldocchi, D. D., Wofsy, S. C., Munger, J. W., Michalsky, J. J., Urbanski, S. P., et al. (2003). Response of a deciduous forest to the Mount Pinatubo Eruption: Enhanced photosynthesis. Science, 299, 2035-2038.

Hollinger, D. Y., Aber, J., Dail, B., Davidson, E. A., Goltz, S. M., Hughes, H., et al. (2004). Spatial and temporal variability in forest-atmosphere $\mathrm{CO}_{2}$ exchange. Global Change Biology, 10, 1689-1706.

June, T., Evans, J. R., \& Farquhar, G. D. (2004). A simple new equation for the reversible temperature dependence of photosynthetic electron transport: A study on soybean leaf. Functional Plant Biology, 31, 275-283.

Keane, R. E., Ryan, K. C., Veblen, T. T., Allen, C. D., Logan, J., \& Hawkes, B. (2002) Cascading effects of fire exclusion in Rocky Mountain ecosystems: A literature review. USDA forest service gen. tech. report RMRS-GTR-91 (24 pp.).

Kicklighter, D. W., Bondeau, A., Schloss, A. L., Kaduk, J., \& Mcguire, A. D.the Participants of the Potsdam NPP model intercomparison. (1999). Comparing global models of terrestrial net primary productivity (NPP): Global pattern and differentiation by major biomes. Global Change Biology, 5, 16-24.

Kindermann, J., Lüdeke, M. K. B., Badeck, F. W., Otto, R. D., Klaudius, A., Häger, C. H., et al. (1993). Structure of a global and seasonal carbon exchange model for the terrestrial biosphere: The Frankfurt Biosphere Model (FBM). Water, Air and Soil Pollution, 70, $675-684$.

Knohl, A., Schulze, E. D., Kolle, O., \& Buchmann, N. (2003). Large carbon uptake by an unmanaged 250-year-old deciduous forest in Central Germany. Agricultural and Forest Meteorology, 118, 151-167.

Kustas, W. P., \& Norman, J. M. (1996). Use of remote sensing for evapotranspiration monitoring over land surfaces. Hydrological Sciences, 41, 495-516.

Landsberg, J. J. (1986). Physiological ecology of forest production (pp. 165-178). London: Academic Press.

Law, B. E., Turner, D., Campbell, J., Sun, O. J., Tuyl, S. V., Ritts, W. D., et al. (2004). Disturbance and climate effects on carbon stocks and fluxes across Western Oregon USA. Global Change Biology, 10, 1429-1444.

Law, B. E., Williams, M., Anthoni, P. M., Baldocchi, D. D., \& Unsworth, M. H. (2000) Measuring and modelling seasonal variation of carbon dioxide and water vapour exchange of a Pinus ponderosa forest subject to soil water deficit. Global Change Biology, 6, 613-630.

Lettenmaier, D. P., \& Famiglietti, J. S. (2006). Water from on high. Nature, 444, 562-563.

Liu, H. P., \& Randerson, J. T. (2008). Interannual variability of surface energy exchange depends on stand age in a boreal forest fire chronosequence. Journal of Geophysical Research, 13, G01006, doi:10.1029/2007JG000483.

Lloyd, J., \& Taylor, J. A. (1994). On the temperature dependence of soil respiration. Functional Ecology, 8, 315-323.

Ma, S., Baldocchi, D. D., Xu, L., \& Hehn, T. (2007). Inter-annual variability in carbon dioxide exchange of an oak/grass savanna and open grassland in California. Agricultural and Forest Meteorology, 147, 157-171.
Marcolla, B., \& Cescatti, A. (2005). Experimental analysis of flux footprint for varying stability conditions in an alpine meadow. Agricultural and Forest Meteorology, 135, 291-301.

Mayocchi, C. L., \& Bristow, K. L. (1995). Soil surface heat flux: some general questions and comments on measurements. Agricultural and Forest Meteorology, 75, 43-50.

McVicar, T. R., \& Jupp, D. L. B. (1998). The current and potential operational uses of remote sensing to aid decisions on drought exceptional circumstances in Australia: A review. Agricultural Systems, 57, 399-468.

Meyer, W. (1999). Standard reference evaporation calculation for inland, south eastern Australia. Technical report, 35/98,Adelaide, South Australia: CSIRO Land and Water

Meyers, T. P. (2001). A comparison of summertime water and $\mathrm{CO}_{2}$ fluxes over rangeland for well watered and drought conditions. Agricultural and Forest Meteorology, 106, 205-214.

Meyers, T. P., \& Hollinger, S. E. (2004). An assessment of storage terms in the surface energy balance of maize and soybean. Agricultural and Forest Meteorology, 125, $105-115$.

Migliavacca, M., Meroni, M., Busetto, L., Colombo, R., Zenone, T., Matteucci, G., et al (2009). Modeling gross primary production of agro-forestry ecosystems by assimilation of satellite derived information in a process-based model. Sensors, 9 922-942.

Monsi, M., \& Saeki, T. (1953). Über den Lichtfaktor in den Pflanzengesellschaften und seine Bedeutung für die Stoffproduktion. Japanese Journal of Botany, 14, 22-52.

Monson, R. K., Sparks, J. P., Rosenstiel, T. N., Scott-Denton, L. E., Huxman, T. E., Harley, P. C., et al. (2005). Climatic influences on net ecosystem $\mathrm{CO}_{2}$ exchange during the transition from wintertime carbon source to springtime carbon sink in a highelevation, subalpine forest. Oecologia, 146, 130-147.

Monteith, J. L. (1972). Solar radiation and productivity in tropical ecosystems. Journal of Applied Ecology, 9, 747-766.

Monteith, J. L. (1977). Climate and the efficiency of crop production in Britain Philosophical Transactions of the Royal Society of London, 281, 277-294.

Mu, Q. Z., Heinsch, F. A., Zhao, M. S., \& Running, S. W. (2007). Development of a global evapotranspiration algorithm based on MODIS and global meteorology data. Remote Sensing of Environment, 111, 519-536.

Noormets, A., Chen, J. Q., \& Crow, T. R. (2007). Age-dependent changes in ecosystem carbon fluxes in managed forests in Northern Wisconsin, USA. Ecosystems, 10 $1432-9840$.

Novick, K. A., Stoy, P. C., Katul, G. G., Ellsworth, D. S., Siqueira, D. S., Juang, J., et al. (2004). Carbon dioxide and water vapor exchange in a warm temperate grassland. Oecologia, 138, 259-274.

Papale, D., Reichstein, M., Aubinet, M., Canfora, E., Bernhofer, C., Kutsch, W., et al. (2006). Towards a standardized processing of Net Ecosystem Exchange measured with eddy covariance technique: Algorithms and uncertainty estimation. Biogeosciences, $3,571-583$.

Pataki, D. E., \& Oren, R. (2003). Species differences in stomatal control of water loss at the canopy scale in a mature bottomland deciduous forest. Advances in Water Resources, 26, 1267-1278.

Paw, U. K. T., Falk, M., Suchanek, T. H., Ustin, S. L., Chen, J. Q., Park, Y. S., et al. (2004) Carbon dioxide exchange between an old-growth forest and the atmosphere. Ecosystems, 7, 513-524.

Pielke, R. S., Sr., Avissar, R., Raupach, M., Dolman, A. J., Zeng, X., \& Denning, A. S. (1998). Interactions between the atmosphere and terrestrial ecosystems: Influence on weather and climate. Global Change Biology, 4, 461-475.

Plöchl, M., \& Cramer, W. (1995). Coupling global models of vegetation structure and ecosystem processes an example from arctic and boreal ecosystems. Tellus(B), 47, $240-250$.

Potter, C. B., Randerson, J. T., Field, C. B., Matson, P. A., Vitousek, P. M., Mooney, H. A., et al. (1993). Terrestrial ecosystem production: A process model based on global satellite and surface data. Global Biogeochemistry Cycle, 7, 811-841.

Rambal, S., Joffre, R., Ourcival, J. M., Cavender-Bares, J., \& Rocheteau, A. (2004). The growth respiration component in eddy $\mathrm{CO}_{2}$ flux from a Quercusilex Mediterranean forest. Global Change Biology, 10, 1460-1469.

Raupach, M. R. (2001). Combination theory and equilibrium evaporation. Quarterly Journal of the Royal Meteorological Society, 127, 1149-1181.

Reichstein, M., Falge, E., Baldocchi, D., Papale, D., Aubinet, M., Berbigier, P., et al. (2005). On the separation of net ecosystem exchange into assimilation and ecosystem respiration: Review and improved algorithm. Global Change Biology, 11, 1424-1439.

Ruimy, A., Kergoat, L., \& Bondeau, A.the Participants of the Potsdam NPP mode intercomparison. (1999). Comparing global models of terrestrial net primary productivity (NPP): analysis of differences in light absorption and light-use efficiency. Global Change Biology, 5, 56-64.

Running S. W., Nemani, R. R., Heinsch, F. A., Zhao, M. S., Reeves, M., \& Hashimoto, H. (2004). A continuous satellite-derived measure of global terrestrial primary production. Bioscience, 54, 547-560.

Running, S. W., Thornton, P. E., Nemani, R., \& Glassy, J. M. (2000). Global terrestrial gross and net primary productivity from the earth observing system. In O. E. Sala, R. B. Jackson, \& H. A. Mooney (Eds.), Methods in ecosystem science (pp. 44-57). New York: Springer-Verlag.

Ryu, Y., Baldocchi, D. D. Ma, S., \& Hehn, T. (2008). Interannual variability of evapotranspiration and energy exchanges over an annual grassland in California. Journal of Geophysical Research-Atmospheres, 113(D09104), doi:10.1029/2007JD009263.

Schimel, D. S. House, J. I., Hibbard, K. A., Bousquet, P. Ciais, P. Peylin, P., et al (2001). Recent patterns and mechanisms of carbon exchange by terrestrial ecosystems. Nature, 414, 169-172.

Schmid, H. P., Grimmond, C. S. B., Cropley, F., Offerle, B., \& Su, H. B. (2000) Measurements of $\mathrm{CO}_{2}$ and energy fluxes over a mixed hardwood forest in the mid-western United States. Agricultural and Forest Meteorology, 103, 357-374. 
Schreiber, L., Skrabs, M., Hartmann, K. D., Diamantopoulos, P., Šimáňová, E., \& Šantrůček, J. (2001). Effect of humidity on cuticular water permeability of isolated cuticular membranes and leaf disks. Planta, 214, 274-282.

Song, J., Liao, K., Coulter, R. L., \& Lesht, B. M. (2005). Climatology of the low-level jet at the southern Great Plains atmospheric Boundary Layer Experiments site. Journal of Applied Meteorology, 44, 1593-1606.

Stoy, P. C., Katul, G. G., Siqueira, M. B. S., Juang, J. Y., Novick, K. A., Mccarthy, H. R., et al (2008). Role of vegetation in determining carbon sequestration along ecological succession in the southeastern United States. Global Change Biology, 14, 1409-1427.

Suyker, A. E., Verma, S. B., Burba, G. G., \& Arkebauer, T. J. (2005). Gross primary production and ecosystem respiration of irrigated maize and irrigated soybean during a growing season. Agricultural and Forest Meteorology, 131, 180-190.

Twine, T. E., Kustas, W. P., Norman, J. M., Cook, D. R., Houser, P. R., Meyers, T. P., et al. (2000). Correcting eddy-covariance flux underestimates over a grassland. Agricultural and Forest Meteorology, 103, 279-300.

Urban, O., Janous, D., Acosta, M., Czerný, R., Markovà, I., Navràtil, M., et al. (2007). Ecophysiological controls over the net ecosystem exchange of mountain spruce stand. Comparison of the response in direct vs. diffuse solar radiation. Global Change Biology, 13, 157-168.

Valentini, R. (2003). Fluxes of carbon, water and energy of European forests.Heidelberg: Springer Verlag (260 pp.)

Verma, S. B., Dobermann, A. Cassman, K. G., Walters, D. T., Knops, J. M., Arkebauer, T. J. et al. (2005). Annual carbon dioxide exchange in irrigated and rainfed maize-based agroecosystems. Agricultural and Forest Meteorology, 131, 77-96.
Vose, J. M., Sullivan, N. H., Clinton, B. D., \& Bolstad, P. V. (1995). Vertical leaf area distribution, light transmittance, and application of the Beer-Lambert Law in four mature hardwood stands in the southern Appalachians. Canadian Journal of Forest Research, 25, 1036-1043.

Whitehead, D., \& Gower, S. T. (2001). Photosynthesis and light-use efficiency by plants in a Canadian boreal forest ecosystem. Tree Physiology, 21, 925-929.

Wilson, K. B., \& Baldocchi, D. D. (2000). Seasonal and interannual variability of energy fluxes over a broadleaved temperate deciduous forest in North American. Agricultural and Forest Meteorology, 100, 1-18.

Yuan, W. P., Liu, S. G., Zhou, G. S., Zhou, G. Y., Tieszen, L. L., Baldocchi, D., et al. (2007). Deriving a light use efficiency model from eddy covariance flux data for predicting daily gross primary production across biomes. Agricultural and Forest Meteorology, $143,189-207$

Zhao, M., Heinsch, F. A., Nemani, R., \& Running, S. W. (2005). Improvements of the MODIS terrestrial gross and net primary production global data set. Remote Sensing of Environment, 95, 164-176.

Zhao, M., Running, S. W., \& Nemani, R. R. (2006). Sensitivity of Moderate Resolution Imaging Spectroradiometer (MODIS) terrestrial primary production to the accuracy of meteorological reanalyses. Journal of Geophysical Research, 111, G01002, doi:10.1029/2004JG000004.

Zhang, Y. C., Rossow, W. B., Lacis, A. A., Oinas, V., \& Mishchenko, M. I. (2004). Calculation of radiative fluxes from the surface to top of atmosphere based on ISCCP and other global data sets: Refinements of the radiative transfer model and the input data. Journal of Geophysical Research, 109, D19105, doi:10.1029/2003JD004457. 